\title{
Biochar and soil properties limit the phytoavailability of lead and cadmium by Brassica chinensis L. in contaminated soils
}

\author{
Assa Albert Houssou ${ }^{1} \cdot$ Paramsothy Jeyakumar ${ }^{2} \cdot$ Nabeel Khan Niazi $^{3} \cdot$ Lukas Van Zwieten $^{4} \cdot$ Xiang Li $^{1}$. \\ Lianxi Huang ${ }^{1} \cdot$ Lan Wei $^{1} \cdot$ Xiaodong Zheng $^{1} \cdot$ Qing Huang ${ }^{1} \cdot$ Yufen Huang ${ }^{1} \cdot$ Xianzhi Huang $^{5} \cdot$ Hailong Wang $^{7,8}$. \\ Zhongzhen Liu $^{1}$ (i) $\cdot$ Zhenrui Huang ${ }^{6}$
}

Received: 6 May 2021 / Accepted: 27 October 2021

(c) The Author(s) 2022

\begin{abstract}
The current study investigated the effect of biochars derived from cinnamomum woodchip, garden waste and mulberry woodchip on soil phytoavailable lead $(\mathrm{Pb})$, cadmium $(\mathrm{Cd})$ pools, and their uptake by Chinese cabbage (Brassica chinensis L.). The biochars were produced at $450{ }^{\circ} \mathrm{C}$ of pyrolysis temperature. The contaminated soils were collected from Yunfu (classified as Udept), Jiyuan (Ustalf) and Shaoguan (Udult) cities in China at the depth of 0-20 cm and amended with biochars at the rate of $3 \% \mathrm{w} / \mathrm{w}$. After mixing the soil with biochar for 14 days, the Chinese cabbage was planted in the amended soils. Then, it was harvested on the 48th day after sowing period. In Udult soil, Chinese cabbage died 18 days after sowing period in control and soils amended with cinnamomum and mulberry biochars. Although only plants grown with the garden waste biochar treatment survived in Udult soil, amendment of garden waste or mulberry biochars at $3 \% \mathrm{w} / \mathrm{w}\left(450{ }^{\circ} \mathrm{C}\right)$ to Udult soil significantly increased (4.95-6.25) soil pH compared to other biochar treatments. In Udept and Ustalf soils, the application of garden waste and mulberry biochars significantly improved plant biomass compared to control, albeit it was dependent on both biochar and soil properties. Garden waste biochar significantly decreased soil Cd phytoavailable concentration by $26 \%$ in the Udult soil, while a decrease of soil Cd phytoavailable concentration by $16 \%$ and $9 \%$ was observed in Ustalf and Udept soils, respectively. The available phosphorus in biochar and soil $\mathrm{pH}$ were important factors controlling toxic metal phytouptake by the plant. Thus, the amendment of soil with biochar at $3 \%$ can effectively reduce the mobility of $\mathrm{Cd}$ and $\mathrm{Pb}$ in soil and plant uptake. However, biochar and soil properties should be well-known before being used for soil toxic metal immobilization.
\end{abstract}

Keywords Contaminant $\cdot$ Feedstock $\cdot$ Available $\mathrm{P} \cdot$ Soil pH, heavy metal

Zhongzhen Liu

lzzgz2001@163.com

$\triangle$ Zhenrui Huang

fjsi@163.com

1 Key Laboratory of Plant Nutrition and Fertilizer in South Region, Ministry of Agriculture, Guangdong Key Laboratory of Nutrient Cycling and Farmland Conservation, Institute of Agricultural Resources and Environment, Guangdong Academy of Agricultural Sciences, Guangzhou 510640, China

2 Environmental Sciences, School of Agriculture and Environment, Massey University, Private Bag 11 222, Palmerston North 4442, New Zealand

3 Institute of Soil and Environmental Sciences, University of Agriculture Faisalabad, Faisalabad 38040, Pakistan
4 Wollongbar Primary Industries Institute, NSW Department of Primary Industries, Wollongbar, Australia

5 State Key Laboratory of Silkworm Genome Biology, Chongqing 400715, China

6 Guangdong Provincial Engineering \& Technology Research Center for Tobacco Breeding and Comprehensive Utilization, Crops Research Institute, Guangdong Academy of Agricultural Sciences, Guangzhou 510640, China

7 Biochar Engineering Technology Research Center of Guangdong Province, School of Environmental and Chemical Engineering, Foshan University, Foshan 528000, China

8 Key Laboratory of Soil Contamination Bioremediation of Zhejiang Province, Zhejiang A\&F University, Hangzhou 311300, China 


\section{Highlights}

- Soil cadmium $(\mathrm{Cd})$ and lead $(\mathrm{Pb})$ phytoavailability vary with biochar and soil types.

- Available P in biochar and soil pH critically affect soil toxic metal phytoavailability.

- Increase in soil $\mathrm{pH}$ resulting from biochar amendment influences plant survival.

- Improvement in soil chemical properties varies with biochar properties.

- Soil pH increase by biochar is more effective in acid soil than in alkaline soil.

\section{Introduction}

Contaminated agricultural soils with toxic metals occur mainly through human activities such as mining, waste disposal, irrigation with wastewater, and application of inorganic and organic fertilizers to agricultural land (Xiao et al. 2019). Previous studies have discovered that crops cultivated in soils polluted with toxic metal(loid)s, e.g., cadmium (Cd), lead $(\mathrm{Pb})$, and arsenic (As), could uptake high concentration of metal(loid)s by roots and accumulate them in their tissues (Gan et al. 2017; Hussain et al. 2021; Li et al. 2020; Natasha et al. 2021; Wen et al. 2021). Both $\mathrm{Cd}$ and $\mathrm{Pb}$ are extremely harmful toxic metals with high mobility in soil-plant environmental system (Jing et al. 2019; Qin et al. 2020). Cadmium and $\mathrm{Pb}$ in soil have been reported in concentrations up to 170 and $775 \mathrm{mg} \mathrm{kg}^{-1}$, respectively, at Moreno field station in California (Qiao et al. 2015). In China, Li et al. $(2016,2018)$ reported that the soil $\mathrm{Cd}$ and $\mathrm{Pb}$ concentrations already reached $26 \mathrm{mg} \mathrm{kg}^{-1}$ and $1699.2 \mathrm{mg} \mathrm{kg}^{-1}$, respectively, which were higher than soil $\mathrm{Cd}$ and $\mathrm{Pb}$ concentrations allowed by Chinese Government $\left(0.3 \mathrm{mg} \mathrm{kg}^{-1}\right.$ for $\mathrm{Cd}$ and $250 \mathrm{mg} \mathrm{kg}^{-1}$ for $\mathrm{Pb}$ ). A recent nationwide survey in China showed that metal concentrations in approximately $19 \%$ of agricultural soils exceeded environmental quality standards (Guan et al. 2018) and the mean concentrations of $\mathrm{Cd}$ and $\mathrm{Pb}$ were about 36.5 and 2.1 folds higher, respectively, than the Grade II environmental quality standard for soils in China (GB15618-18 2018). Various surveys have also shown that heavy metal $\mathrm{Cd}$ and $\mathrm{Pb}$ contamination in soil has become a major problem in the quality of the global environment, particularly in China (Guan et al. 2018). These two metals are difficult to degrade and easy to be enriched by plants (Babalola and Ojuederie 2017). Therefore, $\mathrm{Pb}$ and Cd concentrations in the soil pose a serious threat (Babalola and Ojuederie 2017). According to Qin et al. (2020), toxic metals in contaminated soils negatively affect the plant production by reducing the plant biomass and competing with essential nutrients such as $\mathrm{Ca}, \mathrm{Cu}, \mathrm{Fe}, \mathrm{Zn}$ and $\mathrm{Mn}$. Therefore, negative impacts of $\mathrm{Cd}$ and $\mathrm{Pb}$ on crop can lead to a decrease in nutrient uptake, plant population per hectare and crop yield (Qin et al. 2020). Thus, crops grown in Cd- and $\mathrm{Pb}$-contaminated soil without any pre-treatment may contain higher concentration of these toxic metals in their tissues (Anwar et al. 2020).

To protect public health from contaminated food with toxic metals, different food safety agencies have recommended guidelines for food contaminated by $\mathrm{Cd}$ and $\mathrm{Pb}$. According to Food and Agriculture Organization and World Health Organization (2015), the maximum permissible limit of $\mathrm{Cd}$ in fresh weight vegetables ranges from 0.05 to $0.2 \mathrm{mg} \mathrm{kg}^{-1}$ and that of $\mathrm{Pb}$ ranges from $0.1 \mathrm{mg} \mathrm{Pb} \mathrm{kg}^{-1}$ to $0.3 \mathrm{mg} \mathrm{kg}^{-1}$. However, Mecka et al. (2020) reported that crops cultivated in untreated soil contaminated with $\mathrm{Cd}$ and $\mathrm{Pb}$ can accumulate higher $\mathrm{Cd}$ and $\mathrm{Pb}$ concentrations than those allowed by the guidelines, exposing consumers to risk of physiological disorders and cancer (Gupta et al. 2019; Qin et al. 2020). Thus, understanding the toxic metals uptake by plants can help in protecting living organisms from the impacts (excessive levels can cause cancer, dermal, respiratory, cardiovascular, gastrointestinal, hematological, hepatic, renal, neurological, developmental, reproductive and immune problems) of toxic metals originated from food relationship among them (Ubeynarayana et al. 2021).

Phytoavailability of potentially toxic metals to crop plants is influenced by mobility of toxic metals, soil properties, and environmental conditions (Chen et al. 2018; Lu et al. 2020). Because of the over-riding impact of soil $\mathrm{pH}$ on $\mathrm{Cd}$ and $\mathrm{Pb}$ sorption in soil, Hamid et al. (2020) and Huang et al. (2020) reported that liming acidic soils are generally recognized as being the cost effective and most practical means converting soil exchangeable $\mathrm{Cd}$ and $\mathrm{Pb}$ to $\mathrm{Fe} / \mathrm{Mn}$ oxide- and organicbound metals, thus reducing phytoavailability of $\mathrm{Cd}$ and $\mathrm{Pb}$ to plants. Wu et al. (2020a, b) demonstrated that biochar better improved acidic soil properties ( $\mathrm{pH}$, organic carbon) in comparison to liming. Recently, biochar has been shown to lower the toxic metal mobility in soil because of its active functional groups such as carboxylic acid $(-\mathrm{COOH}),-\mathrm{C}=\mathrm{O}$ and inorganic ionic (e.g., $\mathrm{PO}_{4}$ ) species (Palansooriya et al. 2020; Chen et al. 2021; Pan et al. 2021), which could complex with toxic metals (Lu et al. 2017; Abdin et al. 2019; Xiao et al. 2019), thus, decreasing toxic metal phytoavailability in soil.

The differences in biochar physicochemical properties (functional groups, pore, surface area, phosphorus) mainly depend on the conditions of the pyrolysis process and biochar feedstock (Tomczyk et al. 2020). According to Wei et al. (2020), biochar had large surface, high porosity, pH and concentration of ash and carbon when they were produced from high pyrolysis temperature, but had lower cation exchange capacity (CEC) compared to the biochar produced 
at low pyrolysis temperature. This can be correlated with the carbonization degree (Tomczyk et al. 2020). Eduah et al. (2020) demonstrated that biochars derived from cocoa pod husks, corn cobs, rice husks and palm kernel shells at pyrolysis temperatures of $300{ }^{\circ} \mathrm{C}$ and $650{ }^{\circ} \mathrm{C}$ had similar functional groups such as carboxylic $(-\mathrm{COOH})$, phenolic, aliphatic $\left(-\mathrm{CH}_{2}-\right)$, silicates and carbonate stretch. However, these authors found that the quantity of functional groups depended on pyrolysis temperature and biochar parents. Chen et al. (2018) proposed that the pyrolysis temperature of biochar which can effectively immobilize soil toxic metals should be lower than $500{ }^{\circ} \mathrm{C}$. Thus, lower pyrolysis temperature is economical and produces high-quality of biochar rich in functional groups effectively complexing soil toxic metals (Suliman et al. 2016; Uchimiya et al. 2011). In addition, the biochar originated from non-lignocellusic biomass has higher ash concentration, but lower carbon recovery (Wilk et al. 2019) than that derived from lignocellusic biomass. These differences among biochar properties are related to considerable variation in lignin, cellulose content, and moisture of biochar feedstock (Tomczyk et al. 2020). The soil toxic metal retention by biochar also varies with conditions such as soil organic carbon, texture and $\mathrm{pH}$ (Askeland et al. 2020; Wang et al. 2020).

To sum up, the potentiality of biochars to decrease soil phytoavailable toxic metals and reduce toxic metals assimilated by the plants could be attributed to differences in biochar feedstock properties such as nutrient concentration, active functional groups, and $\mathrm{pH}$ (Yuan and $\mathrm{Xu}$ 2011; Wu et al. 2020a, b). To our knowledge, no research has been reported in literature to explain the effects of contrasting properties of biochars on both $\mathrm{Cd}$ and $\mathrm{Pb}$ phytoavailability in toxic metal contaminated soil types and their influence on metal uptake by vegetable crops. Therefore, the objective of this study was to investigate the impacts of biochars originated from three different feedstocks on soil phytoavailable $\mathrm{Cd}$ and $\mathrm{Pb}$ concentrations and plant uptake using three contrasting soils. We hypothesized that (1) biochar feedstocks may influence the physiochemical properties of biochar, which might result in different modes of action in both acidic and alkaline soils; (2) biochar may change soil $\mathrm{pH}$, which can affect soil $\mathrm{Cd}$ and $\mathrm{Pb}$ phytomobility and their assimilation by the plants.

\section{Materials and methods}

\subsection{Soil and feedstocks of biochar samples}

Soils were collected from three cities in China (Yunfu, Jiyuan and Shaoguan) where soils were contaminated with toxic metals. Yunfu City is located in Guangdong Province
Table 1 Basic soil chemical properties before experiment

\begin{tabular}{llrl}
\hline Property & \multicolumn{1}{l}{ Udept } & \multicolumn{1}{l}{ Ustalf } & \multicolumn{1}{l}{ Udult } \\
\hline Total N $(\%)$ & $0.33 \pm 0.01$ & $0.11 \pm 0.01$ & $0.17 \pm 0.02$ \\
Total $\mathrm{P}\left(\mathrm{g} \mathrm{kg}^{-1}\right)$ & $1.21 \pm 0.02$ & $0.96 \pm 0.03$ & $0.90 \pm 0.01$ \\
$\mathrm{pH}\left(\mathrm{H}_{2} \mathrm{O}\right)$ & $7.26 \pm 0.06$ & $7.55 \pm 1.10$ & $4.9 \pm 0.35$ \\
Total Cd $\left(\mathrm{mg} \mathrm{kg}^{-1}\right)$ & $1.97 \pm 0.01$ & $14.02 \pm 1.35$ & $4.2 \pm 0.41$ \\
Phytoavailable Cd & $0.75 \pm 0.04$ & $5.70 \pm 0.90$ & $2.8 \pm 0.50$ \\
$\quad\left(\mathrm{mg} \mathrm{kg}^{-1}\right)^{\mathrm{a}}$ & & & \\
Total Pb $\left(\mathrm{mg} \mathrm{kg}^{-1}\right)$ & $55 \pm 4.66$ & $855 \pm 6.80$ & $996 \pm 7.60$ \\
Phytoavailable Pb & $6.2 \pm 1.20$ & $274 \pm 5.60$ & $290 \pm 6.80$ \\
$\left(\mathrm{mg} \mathrm{kg}^{-1}\right)^{\mathrm{a}}$ & & & \\
\hline
\end{tabular}

${ }^{\mathrm{a}}$ The soil $\mathrm{Cd}$ and $\mathrm{Pb}$ phytoavailable was estimated using diethylenetriamine pentaacetic acid (DTPA) according the methods described by Mohamad et al. (2015)

in south China, and the soilswere collected from an area $\left(111^{\circ} 03^{\prime}-112^{\circ} 31^{\prime} \mathrm{W}, 22^{\circ} 22^{\prime}-23^{\circ} 19^{\prime} \mathrm{N}\right)$ currently used for crop production such as wheat, rice, maize, potatoes and vegetables. In Jiyuan City, the soils were collected from farmland $\left(112.57^{\circ} \mathrm{E}, 35.13^{\circ} \mathrm{N}\right)$ next to Yuguang Gold Lead Group Co., Ltd. in Kejing Town, Henan province. At present, this farmland is restricted for access due to metal contamination and edible agricultural products are not allowed to grow in this site. In Shaoguan (Dongtang Town, Shaoguan City, Guangdong Province, southern China), the soils were collected near a pyrite mining area $\left(113^{\circ} 30-114^{\circ} 02^{\prime} \mathrm{W}, 24^{\circ}\right.$ $\left.56^{\prime}-25^{\circ} 27^{\prime} \mathrm{N}\right)$. Mining and smelting activities near Dongtang began in 1958 and toxic metal contamination caused by deposition of toxic metals from atmospheric and irrigation of crop with wastewater has increased annually (Luo et al. 2019). The area where we collected soil is currently restricted for access and the cultivation of edible agricultural products is forbidden.

Soil samples were collected from three sites at top $20 \mathrm{~cm}$ depth using a blade of shovel. The soil sample were air-dried 4 weeks. The subsamples were taken from air-dried bulk soils and sieved through 2-mm size and kept for the chemical analysis and pot experiment. The soil collected from Yunfu, Jiyuan and Shaoguan belong to 'Udept', 'Ustalf' and 'Udult' soil groups, respectively, based on the Soil Taxonomy of the United States. All these three types of soils are heavily contaminated (Table 1) with lead $(\mathrm{Pb})$ exceeding guideline values $\left(250 \mathrm{mg} \mathrm{kg}^{-1}\right)$ suggested by the China National Environmental Quality Standard for Soils (GB15618-2018 2018). The Cd concentration of the Udept soil did not exceed the guideline $\left(0.3 \mathrm{mg} \mathrm{kg}^{-1}\right)$ values suggested by GB15618-2018 (2018), but the Ustalf and Udult soils exceeded $0.3 \mathrm{mg} \mathrm{kg}^{-1}$ soil, the threshold of soil concentration.

Three biochars were derived from three different feedstocks including cinnamomum woodchips, garden waste (that was partially compost and mainly contained leaves) and mulberry woodchips. The collected feedstocks were 
Table 2 Physico-chemical properties of biochars produced from three different feedstocks at pyrolysis temperature of $450{ }^{\circ} \mathrm{C}$

\begin{tabular}{|c|c|c|c|}
\hline Property & $\begin{array}{l}\text { Cinnamomum } \\
\text { biochar }\end{array}$ & $\begin{array}{l}\text { Garden waste } \\
\text { biochar }\end{array}$ & Mulberry biochar \\
\hline Organic carbon $(\%)$ & 57 & 61 & 50.82 \\
\hline $\mathrm{pH}\left(\mathrm{H}_{2} \mathrm{O}\right)$ & 4.25 & 9.45 & 9.28 \\
\hline Total potassium $\left(\mathrm{g} \mathrm{kg}^{-1}\right)$ & 3.1 & 22 & 24.29 \\
\hline Available potassium $\left(\mathrm{g} \mathrm{kg}^{-1}\right)$ & 1.1 & 1.8 & 1.14 \\
\hline Total N (\%) & 0.60 & 1.23 & 1.39 \\
\hline Available $\mathrm{N}\left(\mathrm{g} \mathrm{kg}^{-1}\right)$ & 0.06 & 0.11 & 0.09 \\
\hline Total phosphorus (\%) & 0.06 & 0.36 & 0.54 \\
\hline Available phosphorus $\left(\mathrm{g} \mathrm{kg}^{-1}\right)$ & 0.03 & 0.78 & 1.56 \\
\hline Total $\mathrm{Cd}$ concentration $\left(\mathrm{mg} \mathrm{kg}^{-1}\right)$ & 0.16 & 0.25 & 0.11 \\
\hline Total $\mathrm{Pb}\left(\mathrm{mg} \mathrm{kg}^{-1}\right)$ & 2.34 & 10.56 & 1.69 \\
\hline Ash (\%) & 4.2 & 29 & 9.75 \\
\hline $\mathrm{C}(\%)$ (no carbonate) & 83 & 56 & 76.83 \\
\hline $\mathrm{H}(\%)$ & 3.01 & 2.95 & 3.77 \\
\hline $\mathrm{S}(\%)$ & 0.12 & 0.21 & 0.10 \\
\hline $\mathrm{O}(\%)$ & 14 & 39 & 18.10 \\
\hline $\mathrm{H} / \mathrm{C}$ in molar ratio & 0.44 & 0.63 & 0.59 \\
\hline $\mathrm{O} / \mathrm{C}$ in molar ratio & 0.13 & 0.52 & 0.18 \\
\hline Surface area of Brunauer-Emmett-Teller $\left(\mathrm{m}^{2} \mathrm{~g}^{-1}\right)$ & 1.97 & 2.24 & 1.24 \\
\hline Pore size of Barrett-Joyner-Halenda (nm) & 11 & 16 & 24.86 \\
\hline
\end{tabular}

crushed and sieved through a 2-mm to maintain the uniformity of individual materials. Garden waste was provided by Dadi Garden Environmental Engineering Co., Ltd (Shunde City in Guangdong province). The biochars derived from dry feedstocks were produced in South China Agricultural University using a biomass carbonization furnace at $450{ }^{\circ} \mathrm{C}$ in an oxygen-limited condition. The biochars were chilled to room temperature in steel tanks after pyrolysis and kept until used for the chemical analysis and pot experiment. The heating rate was $8{ }^{\circ} \mathrm{C} \mathrm{min}-1$ with the residence time of $3 \mathrm{~h}$.

\subsection{Soil and biochar sample analysis}

Properties of biochar and soil were determined following $\mathrm{Lu}$ (2000) procedure. The $\mathrm{pH}$ of biochar and soil were ( $\mathrm{Wu}$ et al. 2020a, b) analyzed (in 2.5:1 water/soil (w/w) suspension after stirring) with a $\mathrm{pH}$ electrode (In Lab Expert Pro, order $\mathrm{N}^{\mathrm{o}}$ 51343101). The soil toxic metals ( $\mathrm{Cd}$ and $\mathrm{Pb}$ ) phytoavailable were determined using diethylene triamine pentaacetic acid (DTPA) according to Mohamad et al. (2015) methods [the flame atomic absorption spectrometry (Varian AA240FS) after $\mathrm{H}_{2} \mathrm{SO}_{4} / \mathrm{HClO}_{4}(2: 1$ ratio v/v) digestion] reported by Zhou et al. (2017). The soil $\mathrm{Cd}$ and $\mathrm{Pb}$ phytoavailable concentrations and total $\mathrm{Cd}$ and $\mathrm{Pb}$ concentrations in biochar and cabbage tissues were determined with a flame polarized Zeeman atomic absorption spectrophotometer (same model as previously described). Biochar ultimate properties such as $\mathrm{C}, \mathrm{H}, \mathrm{O}$ and $\mathrm{S}$ concentrations were determined with an elemental analyzer (FlashSmart, Thermofisher, USA).

Biochar surface area was measured using Brunauer-Emmett-Teller analysis. Thus, the biochar samples were degassed for $12 \mathrm{~h}$ at $105{ }^{\circ} \mathrm{C}$ before the measurement of specific surface area. To calculate biochar specific surface area and pore diameter, we used Barrett-Joyner-Halenda method. Available phosphorus, nitrogen and potassium in biochar were determined according to Camps-Arbestain et al. (2015) method.

The chemical properties of soil before experiment are reported in Table 1 whereas the biochar properties are summarized in Table 2 .

\subsection{Pot experiment}

The experiments were performed in greenhouse of Guangdong Academy of Agricultural Sciences. The greenhouse temperatures were maintained at $8 \pm 0.6{ }^{\circ} \mathrm{C}$ minimum (night) and $29 \pm 0.4{ }^{\circ} \mathrm{C}$ maximum (day). The experiments were set up using the three soils each with the following treatments: control (no biochar), cinnamomum biochar, garden waste biochar and mulberry biochar with 4 replicates resulting in a total of 48 pots in the experiment. In each pot, $0.105 \mathrm{~kg}$ of biochar was individually and uniformly mixed with $3.50 \mathrm{~kg}$ of air-dried contaminated soil, to obtain an amendment rate $3 \%(\mathrm{w} / \mathrm{w})$ of biochar to contaminated soil. The biochar amended and control soils were incubated for 2 weeks in the same greenhouse, around 10 Chinese cabbage (Brassica 
chinensis L.) seeds were sown in the pot and reduced to four healthy plants at 8 days after sowing. Ten days after emergence of seedling, uniform rates of $\mathrm{N}, \mathrm{K}$ and $\mathrm{P}$ were applied to the soil at the rates of $100 \mathrm{mg} \mathrm{kg}^{-1}, 100 \mathrm{mg} \mathrm{kg}^{-1}$, and $80 \mathrm{mg} \mathrm{kg}^{-1}$, respectively. The pots were arranged in completely randomized design and soil water content was kept at $70 \%$ of the pot field capacity for the 48 days of experimental duration.

\subsection{Plant and soil sampling at harvest and analysis}

At the end of 48 days, plants and soils were manually collected for laboratory work. The collected plants were washed with deionized water, carefully classified into roots (all parts of the plant that lie below the surface of the soil), stems, petioles, blades and weighed. To get the constant weight of plant material, we dried the plant material at $70{ }^{\circ} \mathrm{C}$. After weighing, all dry biomass from each part of the plant was manually ground with mortar and pestle and kept for further chemical analysis. Subsamples from each biomass component $(0.2 \mathrm{~g})$ were taken and digested into $\mathrm{HNO}_{3}(5 \mathrm{ml}$ with $65 \%)$ and $\mathrm{HClO}_{4}(1 \mathrm{ml}$ with $71 \%)$ for $4 \mathrm{~h}$ at $120^{\circ} \mathrm{C}, 4 \mathrm{~h}$ at $150{ }^{\circ} \mathrm{C}$ and $4 \mathrm{~h}$ at $180{ }^{\circ} \mathrm{C}$ (Zhou et al. 2017). The extracts obtained at the end of digestion were diluted with deionized water to $25 \mathrm{ml}$ and analyzed for $\mathrm{Cd}$ and $\mathrm{Pb}$ concentrations using a flame polarized zeeman atomic absorption spectrophotometer (Model: ZA3300AA, Spectrophotometer 220V, model: 7J1-8327 with a Serial number of 2661-001).

The soil samples obtained from pots were air-dried for 2 weeks without any risk of the soil properties changed. The dried soils were crushed and sieved with a $2 \mathrm{~mm}$ sieve. Soil properties such as $\mathrm{TN}, \mathrm{TP}$, available $\mathrm{Cd}$ and $\mathrm{Pb}$ were analyzed as reported in the Sect. 2.4.

To compare the control to the treatment, the change in soil toxic metal concentration induced by biochar across the soil type was estimated as follows: biochar immobilization and uptake of soil toxic metals, the principal components analysis (PCA) was used to identify the correlations among biochars chemical characteristics (available phosphorus, potassium, nitrogen), soil properties $(\mathrm{pH}$, phytoavailable $\mathrm{Pb}$ and $\mathrm{Cd}$ ), dry shoots and roots biomass and toxic metal concentrations in shoot and root. All statistical analyses of biomass, soil $\mathrm{Cd}$ and $\mathrm{Pb}$ phytoavailable and plant uptake were conducted with SPSS, version 23 (SPSS Institute, USA 2007).

\section{Results}

\subsection{Effect of biochar and soil types on plant biomass production}

The biochar produced from cinnamomum woodchips had a $\mathrm{pH}$ of $4.25\left(\mathrm{H}_{2} \mathrm{O}\right)$ contrasting to the biochar produced from garden waste ( $\mathrm{pH}$ was 9.45) and mulberry feedstock ( $\mathrm{pH}$ was 9.28). The biochar derived from cinnamomum had the lowest $\mathrm{N}, \mathrm{P}$ and $\mathrm{K}$ concentrations and the lowest $\mathrm{H} / \mathrm{C}$ and $\mathrm{O} / \mathrm{C}$ molar ratios suggesting a greater degree of carbonization of biochar derived from cinnamomum (Table 2).

During the study, plants which were cultivated in the Udept and Ustalf soils survived until the harvest period. The plants cultivated in the Udult soil died 18 days after sowing period, except the plants grown in Udult soil amended with garden waste biochar (Table 3). Amended Udept soil with garden waste biochar significantly increased the dry root, stem and total dry plant biomass compared to other biochar treatments and control (Table 3). The total dry biomass under garden waste biochar was estimated at $4.83 \pm 0.34 \mathrm{~g} \mathrm{DM}$ plant $^{-1}$. However, similar results were recorded between gardenwaste-and mulberry-derived biochars for petiole, blade and shoot biomass produc-

$$
\text { STMC }(\%)=\frac{\text { Avarage of soil phytoavailable toxic metals in contol }- \text { soil phytoavailabe toxic metals in treatment }}{\text { Average of soil phytoavailable toxic metals in control }} \times 100
$$

where STMC stands for soil toxic metal change in the treated soil compared to control across the three soil types.

The soil toxic metal change in treatment compared to control was used to make a comparison among potentially toxic metal changes induced by a biochar across the three soil types.

\subsection{Data processing and statistics}

We reported data as means with standard error. Differences among biochar treatments and control were investigated with one-way analysis of variance. To identify the mechanisms of tion. In addition, the mulberry biochar produced a greater $(\mathrm{P}>0.05)$ total biomass $\left(3.92 \pm 0.40 \mathrm{~g} \mathrm{DM}\right.$ plant $\left.^{-1}\right)$ compared to biomass production in cinnamomum biochar $\left(3.51 \pm 0.16 \mathrm{~g} \mathrm{DM}\right.$ plant $\left.^{-1}\right)$. The untreated soil had the lowest total biomass of $3.06 \pm 0.19 \mathrm{~g} \mathrm{DM}$ plant $^{-1}$. In the Ustalf soil, similar results $(\mathrm{P}>0.05)$ were detected among treatments except for stem and petiole biomass, where mulberry biochar significantly produced the highest biomass $\left(0.29 \pm 0.04 \mathrm{~g} \mathrm{DM} \mathrm{plant}^{-1}\right.$ for stem; $1.03 \pm 0.06 \mathrm{~g} \mathrm{DM} \mathrm{plant}^{-1}$ for petiole) compared to control $\left(0.17 \pm 0.01 \mathrm{~g} \mathrm{DM}\right.$ plant $^{-1}$ for stem; $0.74 \pm 0.01 \mathrm{~g} \mathrm{DM}$ plant $^{-1}$ for petiole). For stem and petiole biomass, a similar biomass pattern was observed 
Table 3 Average biomass dry weight of Chinese cabbage as affected by different biochars and soil types

\begin{tabular}{|c|c|c|c|c|c|c|c|}
\hline \multirow[t]{2}{*}{ Soil types } & \multirow[t]{2}{*}{ Treatments } & \multicolumn{5}{|c|}{ 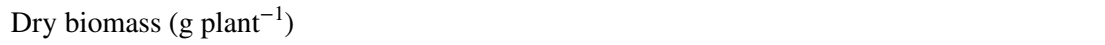 } & \multirow[t]{2}{*}{ Total } \\
\hline & & Root & Stem & Petiole & Blade & Shoot & \\
\hline \multirow[t]{4}{*}{ Udept } & Control & $0.18 \pm 0.01 b$ & $0.24 \pm 0.04 b$ & $0.87 \pm 0.03 b$ & $1.78 \pm 0.14 b$ & $2.88 \pm 0.0 .18 b$ & $3.06 \pm 0.19 b$ \\
\hline & CIBC & $0.23 \pm 0.02 b$ & $0.29 \pm 0.01 b$ & $1.05 \pm 0.09 b$ & $1.95 \pm 0.09 b$ & $3.29 \pm 0.15 b$ & $3.51 \pm 0.16 b$ \\
\hline & GABC & $0.35 \pm 0.02 \mathrm{a}$ & $0.47 \pm 0.06 \mathrm{a}$ & $1.50 \pm 0.07 \mathrm{a}$ & $2.52 \pm 0.20 \mathrm{a}$ & $4.49 \pm 0.32 \mathrm{a}$ & $4.83 \pm 0.34 a$ \\
\hline & MUBC & $0.23 \pm 0.03 b$ & $0.30 \pm 0.05 b$ & $1.19 \pm 0.18 \mathrm{ab}$ & $2.22 \pm 0.16 \mathrm{ab}$ & $3.70 \pm 0.39 \mathrm{ab}$ & $3.92 \pm 0.40 b$ \\
\hline \multirow[t]{4}{*}{ Ustalf } & Control & $0.18 \pm 0.04$ & $0.17 \pm 0.01 b$ & $0.74 \pm 0.10 b$ & $1.51 \pm 0.20$ & $2.42 \pm 0.30$ & $2.60 \pm 0.33$ \\
\hline & CIBC & $0.14 \pm 0.02$ & $0.25 \pm 0.01 \mathrm{ab}$ & $0.95 \pm 0.07 \mathrm{ba}$ & $1.78 \pm 0.09$ & $2.98 \pm 0.11$ & $3.12 \pm 0.13$ \\
\hline & GABC & $0.13 \pm 0.04$ & $0.23 \pm 0.04 \mathrm{ab}$ & $0.82 \pm 0.08 \mathrm{ab}$ & $1.59 \pm 0.26$ & $2.63 \pm 0.38$ & $2.77 \pm 0.41$ \\
\hline & MUBC & $0.14 \pm 0.01$ & $0.29 \pm 0.04 \mathrm{a}$ & $1.03 \pm 0.06 \mathrm{a}$ & $1.82 \pm 0.09$ & $3.13 \pm 0.11$ & $3.27 \pm 0.12$ \\
\hline \multirow[t]{4}{*}{ Udult } & Control & Not available & Not available & Not available & Not available & Not available & Not available \\
\hline & $\mathrm{CIBC}$ & Not available & Not available & Not available & Not available & Not available & Not available \\
\hline & GABC & $0.17 \pm 0.03$ & $0.22 \pm 0.03$ & $1.06 \pm 0.11$ & $1.90 \pm 0.03$ & $3.19 \pm 0.15$ & $3.36 \pm 0.15$ \\
\hline & MUBC & Not available & Not available & Not available & Not available & Not available & Not available \\
\hline
\end{tabular}

Control: No biochar application; CIBC: Cinnamomum biochar; GABC: Garden waste biochar; MUBC: Mulberry biochar

Not available because the plant died about 10 days after thinness period. Values are mean with standard error ( $\mathrm{n}=4$ replicates). The means with different letters in a column under a soil type indicate that they are significantly $(\mathrm{P}<0.05)$ different

Table 4 Soil total nitrogen: TN, phosphorus: TP, $\mathrm{pH}$, phytoavailable $\mathrm{Cd}$ : $\mathrm{AvCd}$ and $\mathrm{Pb}$ : $\mathrm{AvPb}$ as affected by biochars and soils

\begin{tabular}{|c|c|c|c|c|c|c|}
\hline Soil types & Treatments & $\mathrm{TN}(\%)$ & $\mathrm{TP}\left(\mathrm{g} \mathrm{kg}^{-1}\right)$ & $\mathrm{pH}\left(\mathrm{H}_{2} \mathrm{O}\right)$ & Available $\mathrm{Pb}\left(\mathrm{mg} \mathrm{kg}^{-1}\right)$ & Available Cd $\left(\mathrm{mg} \mathrm{kg}^{-1}\right)$ \\
\hline \multirow[t]{4}{*}{ Udept } & Control & $0.33 \pm 0.00$ & $2.37 \pm 0.04$ & $7.42 \pm 0.08$ & $5.51 \pm 0.20$ & $0.72 \pm 0.01 \mathrm{a}$ \\
\hline & CIBC & $0.34 \pm 0.01$ & $2.65 \pm 0.17$ & $7.48 \pm 0.02$ & $4.48 \pm 0.83$ & $0.71 \pm 0.02 \mathrm{a}$ \\
\hline & GABC & $0.34 \pm 0.01$ & $2.66 \pm 0.31$ & $7.52 \pm 0.02$ & $5.95 \pm 0.36$ & $0.65 \pm 0.01 b$ \\
\hline & MUBC & $0.34 \pm 0.00$ & $2.57 \pm 0.17$ & $7.44 \pm 0.02$ & $5.40 \pm 0.27$ & $0.67 \pm 0.00 b$ \\
\hline \multirow[t]{4}{*}{ Ustalf } & Control & $0.17 \pm 0.00 \mathrm{c}$ & $1.40 \pm 0.13 b$ & $7.40 \pm 0.04$ & $264.10 \pm 8.20 \mathrm{ab}$ & $5.85 \pm 0.11 \mathrm{a}$ \\
\hline & $\mathrm{CIBC}$ & $0.17 \pm 0.00 \mathrm{c}$ & $1.39 \pm 0.08 b$ & $7.45 \pm 0.04$ & $268.98 \pm 6.50 \mathrm{a}$ & $5.97 \pm 0.10 \mathrm{a}$ \\
\hline & GABC & $0.18 \pm 0.00 \mathrm{~b}$ & $1.74 \pm 0.08 \mathrm{a}$ & $7.49 \pm 0.02$ & $246.31 \pm 2.01 b$ & $4.94 \pm 0.09 b$ \\
\hline & MUBC & $0.20 \pm 0.01 \mathrm{a}$ & $1.70 \pm 0.06 \mathrm{a}$ & $7.54 \pm 0.06$ & $258.08 \pm 3.19 \mathrm{ab}$ & $5.26 \pm 0.26 b$ \\
\hline \multirow[t]{4}{*}{ Udult } & Control & $0.21 \pm 0.01$ & $1.16 \pm 0.03 b$ & $4.40 \pm 0.14 \mathrm{c}$ & $349.82 \pm 1.65 \mathrm{a}$ & $3.30 \pm 0.11 \mathrm{a}$ \\
\hline & CIBC & $0.24 \pm 0.01$ & $1.36 \pm 0.07 \mathrm{a}$ & $4.23 \pm 0.06 c$ & $343.03 \pm 2.63 \mathrm{a}$ & $3.04 \pm 0.12 \mathrm{ab}$ \\
\hline & GABC & $0.23 \pm 0.01$ & $1.33 \pm 0.03 a$ & $6.25 \pm 0.08 \mathrm{a}$ & $291.37 \pm 2.41 b$ & $2.43 \pm 0.04 \mathrm{c}$ \\
\hline & MUBC & $0.24 \pm 0.01$ & $1.39 \pm 0.07 \mathrm{a}$ & $4.95 \pm 0.017 b$ & $294.24 \pm 6.50 b$ & $2.97 \pm 0.09 b$ \\
\hline
\end{tabular}

Control: No biochar application, CIBC: Cinnamomum biochar, GABC: Garden waste biochar, MUBC: Mulberry biochar

The means with different letters in a column under a soil type indicate that they were significantly $(\mathrm{P}<0.05)$ different

among control, cinnamomum and garden waste biochars in Ustalf soil.

\subsection{Soil chemical properties induced by biochar produced from different feedstocks}

The properties of biochar significantly influenced soil parameters across the three soil types (Table 4). The phytoavailable $\mathrm{Cd}$ concentration of control soil was different among three soil types and increased in the following order Udept $\left(0.72 \pm 0.01 \mathrm{mg} \mathrm{kg}^{-1}\right)<$ Udult $\left(3.30 \pm 0.11 \mathrm{mg} \mathrm{kg}^{-1}\right)<$ Ustalf $\left(5.85 \pm 0.11 \mathrm{mg} \mathrm{kg}^{-1}\right)$. Similarly, Udept $5.51 \pm 0.20 \mathrm{mg} \mathrm{kg}^{-1}$ showed the lowest soil-phytoavailable $\mathrm{Pb}$ concentration followed by Ustalf $\left(264.10 \pm 8.2 \mathrm{mg} \mathrm{kg}^{-1}\right)$ and Udult $\left(349.82 \pm 1.65 \mathrm{mg} \mathrm{kg}^{-1}\right)$.

Amending the Udept and Ustalf soils with garden waste and mulberry biochars significantly decreased $(\mathrm{P}<0.05)$ soil phytoavailable $\mathrm{Cd}$ concentration compared to cinnamomum biochar treatment and control (Table 4), which did not display any similarity results between them. A similar result was observed between mulberry and garden waste biochars in Udept and Ustalf soils and no significant difference was recorded between them for soil phytoavailable $\mathrm{Cd}$ concentration. However, the amendment of Udult soil with garden waste biochar effectively (with $\mathrm{P}<0.01)$ decreased $(26 \%)$ the phytoavailable $\mathrm{Cd}$ concentration significantly followed 


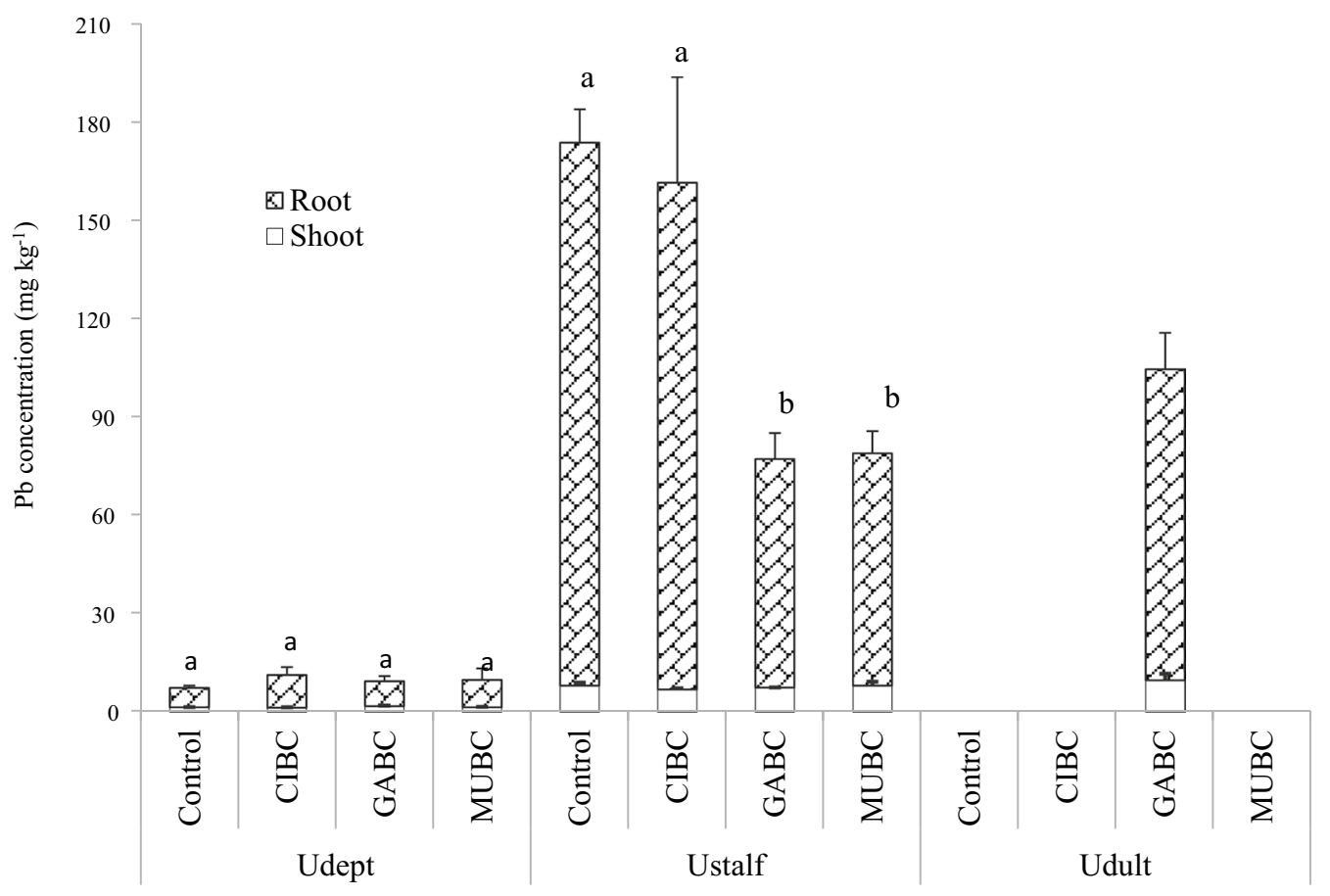

Fig. 1 Effects of biochar on $\mathrm{Pb}$ concentrations in plant tissues. Control: No biochar application; CIBC: Cinnamomum biochar; GABC: Garden waste biochar; MUBC: Mulberry biochar. Values are mean with standard error ( $\mathrm{n}=4$ replicates). For Udult, the plant tissue $\mathrm{Pb}$

by mulberry biochar amendment (10\%) compared to untreated soil. In Udult soil, no significant $(\mathrm{P}>0.05)$ difference was recorded between cinnamomum biochar treatment and untreated soil for soil phytoavailable $\mathrm{Cd}$ concentration.

For the soil phytoavailable $\mathrm{Pb}$ concentration, there were no significant differences $(\mathrm{P}>0.05)$ among treatments in Udept soil. For Ustalf soil, garden waste biochar significantly (with $\mathrm{P}<0.05$ ) decreased soil $\mathrm{Pb}$ concentration (8\%) compared to cinnamomum biochar treatment; however, similar results were obtained among control, cinnamomum and mulberry biochar treatments (Table 4). The soil $\mathrm{Pb}$ concentration in Ustalf soil was estimated at $246.31 \pm 2.01 \mathrm{mg} \mathrm{kg}^{-1}$ with garden waste biochar amendment. The amendment of Udult soil with garden waste and mulberry biochars effectively reduced $(\mathrm{P}<0.01)$ soil $\mathrm{Pb}$ phytoavailable concentration compared to untreated soil and cinnamomum treatment. For the soil $\mathrm{pH}$, no significant $(\mathrm{P}>0.05)$ differences wereobserved among treatments under Udept and Ustalf, which were both alkaline soils. However, in acidic Udult soil (Table 4), garden waste biochar significantly (with $\mathrm{P}<0.01)$ improved $(6.25 \pm 0.08)$ soil $\mathrm{pH}$ compared to cinnamomum $(4.23 \pm 0.06)$, mulberry $(4.95 \pm 0.017)$ and control $(4.40 \pm 0.14)$. Furthermore, amended Udult soil with mulberry biochar significantly increased $(\mathrm{P}<0.01)$ soil $\mathrm{pH}$ concentrations on control, CIBC, and MUBC were not measured because the plants were died about 10 days after thinness period. The means with different letters under a soil type indicate that they are significantly $(\mathrm{P}<0.05)$ different

compared to control; however, no significant differences were recorded between the soil $\mathrm{pH}$ induced by cinnamomum biochar and control. For the soil total P, similar result patterns were detected among treatments in Udept soil; however, in the Ustalf soil, garden waste and mulberry biochars significantly induced a high soil total $\mathrm{P}$ concentration compared to that induced by cinnamomum biochar treatment and control. The garden waste and mulberry biochars increased soil total $\mathrm{P}$ by $24 \%$ and $21 \%$ respectively, in comparison to untreated soil. There was no significant $(\mathrm{P}>0.05)$ difference between cinnamomum treatment and control for concentration of soil total $\mathrm{P}$ in Ustalf soil. In addition, a similar pattern of soil total $\mathrm{P}$ concentration was recorded between garden waste and mulberry biochars in Ustalf soil. The amendment of cinnamomum, garden waste and mulberry biochars to the Udult soil significantly improved the soil total $\mathrm{P}$ concentration compared to untreated soil. No significant $(\mathrm{P}>0.05)$ differences were observed in total $\mathrm{N}$ among biochar treatments in Udept and Udult soils; however, in Ustalf, mulberry biochar treatment significant induced the highest soil total $\mathrm{N}$ followed by garden waste biochar treatment, which had significantly higher soil total $\mathrm{N}$ compared to cinnamomum biochar and untreated soils. 


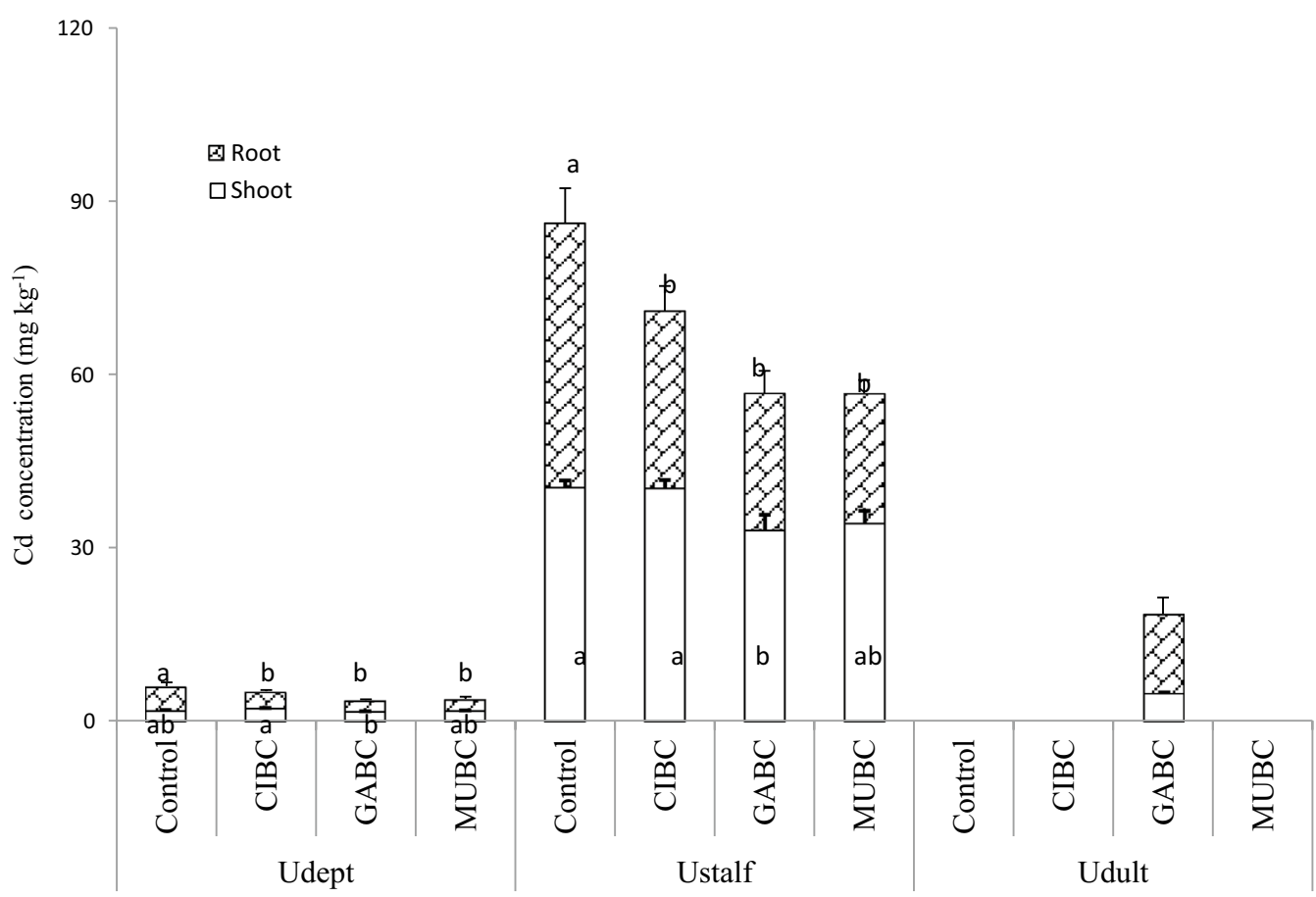

Fig. 2 Effects of biochar on Cd concentrations in plant tissues. Control: No biochar application; CIBC: Cinnamomum biochar; GABC: Garden waste biochar; MUBC: Mulberry biochar. Values are mean with standard error $(n=4$ replicates). For Udult, the plant tissue $\mathrm{Cd}$

\subsection{Influence of biochar on plant tissue $\mathrm{Cd}$ and $\mathrm{Pb}$ concentrations}

No significant differences were detected among biochar treatments for shoot and root $\mathrm{Pb}$ concentrations in Udept soil (Fig. 1). However, significant differences were detected among treatments for $\mathrm{Pb}$ concentration in the roots of plants cultivated in the Ustalf soil (Fig. 1). A significant reduction in $\mathrm{Pb}$ concentration $(\mathrm{P}<0.05)$ of root was detected under garden waste $\left(69 \pm 8.00 \mathrm{mg} \mathrm{kg}^{-1} \mathrm{DM}\right)$ and mulberry $\left(70.79 \pm 6.81 \mathrm{mg} \mathrm{kg}^{-1} \mathrm{DM}\right)$ biochar amendments compared to cinnamomum biochar $\left(154.40 \pm 32.30 \mathrm{mg} \mathrm{kg}^{-1} \mathrm{DM}\right)$ and the untreated soil $\left(165.42 \pm 10.2 \mathrm{mg} \mathrm{kg}^{-1} \mathrm{DM}\right)$ in the Ustalf soil. Although the garden waste and mulberry biochar application significantly reduced the $\mathrm{Pb}$ concentration in roots compared to untreated soil and cinnamomum biochar treatment, no significant differences were detected $(\mathrm{P}>0.05)$ in shoot $\mathrm{Pb}$ concentration among treatments in the Ustalf soil. Furthermore, no significant $(\mathrm{P}>0.05)$ difference was detected between cinnamomum biochar treatment and the untreated soil, and also between garden waste and mulberry biochar treatments for $\mathrm{Pb}$ concentration of root in the Ustalf soil. In addition, the highest shoot and root $\mathrm{Pb}$ concentrations were obtained in Udult followed by that recorded in Ustalf and Udept for garden waste biochar treatment (to make the rank, we only considered garden waste biochar concentrations on control, CIBC, and MUBC were not measured because the plants were died about 10 days after thinness period. The means with different letter under a soil type indicate that they are significantly $(\mathrm{P}<0.05)$ different

treatment across the three types of soil because the plants died in Udult soil except in Udult soil amended with garden waste biochar). The potential toxic metal concentrations were not estimated for the roots and shoots under control, cinnamomum and mulberry biochar treatments in Udult soil (Fig. 1) because all the plants died 18 days after sowing period.

For the plant Cd tissue concentrations in Udept soil, the biochar amendment significantly reduced the root $\mathrm{Cd}$ concentration (Fig. 2) compared to untreated soil $(\mathrm{P}<0.01)$. Among biochar treatments, the highest reduction in root $\mathrm{Cd}$ concentration in Udept soil was obtained with garden waste biochar treatment whereas the lowest reduction in $\mathrm{Cd}$ concentration of root was obtained with cinnamomum biochar treatment compared to untreated soil. Furthermore, garden waste biochar treatment significantly (with $\mathrm{P}<0.01$ ) induced the lowest shoot $\mathrm{Cd}$ concentration compared to that induced by cinnamomum biochar amendment and no significant difference was obtained among control, cinnamomum and mulberry biochar treatments (Fig. 2) for shoot $\mathrm{Cd}$ concentration in Udept soil. In Ustalf soil (Fig. 2), the application of all types of biochar also significantly decreased Cd concentration in roots compared to untreated soils.

The highest reduction in $\mathrm{Cd}$ root concentration was detected in Ustalf soil amended with garden waste biochar followed by that observed in Ustalf amended with mulberry 
Table 5 Toxic metal concentration change (\%) following biochar treatments compared to untreated soil

\begin{tabular}{|c|c|c|c|c|c|c|}
\hline \multirow[t]{2}{*}{ Soil types } & \multicolumn{3}{|c|}{ Soil phytoavailable $\mathrm{Cd}$ concentration } & \multicolumn{3}{|c|}{ Soil pytoavailable $\mathrm{Pb}$ concentration } \\
\hline & CIBC & GABC & MUBC & CIBC & GABC & MUBC \\
\hline Udept $(\mathrm{N}=4)$ & $1.04 \pm 2.22 \mathrm{ab}$ & $9.38 \pm 1.31 \mathrm{c}$ & $6.94 \pm 0.57$ & $5.09 \pm 2.55$ & $-7.87 \pm 6.48 b$ & $2.03 \pm 4.85 b$ \\
\hline Ustalf $(\mathrm{N}=4)$ & $-2.01 \pm 1.71 b$ & $15.61 \pm 1.45 b$ & $10.00 \pm 4.89$ & $-1.84 \pm 2.46$ & $6.74 \pm 0.76 \mathrm{a}$ & $2.28 \pm 1.21 \mathrm{~b}$ \\
\hline Udult $(\mathrm{N}=4)$ & $7.88 \pm 3.57 \mathrm{a}$ & $26.29 \pm 1.23 \mathrm{a}$ & $10.08 \pm 2.84$ & $1.94 \pm 0.75$ & $16.71 \pm 0.69 \mathrm{a}$ & $15.89 \pm 1.86 \mathrm{a}$ \\
\hline Overall $(\mathrm{N}=12)$ & $2.30 \pm 1.85 \mathrm{c}$ & $17.08 \pm 2.22 \mathrm{a}$ & $9.00 \pm 21.72 b$ & $1.73 \pm 1.36$ & $5.19 \pm 3.63$ & $6.73 \pm 2.53$ \\
\hline
\end{tabular}

CIBC: Cinnamomum biochar, GABC: Garden waste biochar, MUBC: Mulberry biochar

Values are average with standard error. The means with different letters in a column under a soil type indicate that they were significantly $(\mathrm{P}<0.05)$ different. For overall $\mathrm{Cd}$ change, the means with different letters within a row indicate that they were significantly $(\mathrm{P}<0.05)$ different

and cinnamoum biochars. For shoot $\mathrm{Cd}$ concentration in the Ustalf soil, the application of garden waste biochar significantly $(\mathrm{P}<0.05)$ induced the lowest shoot $\mathrm{Cd}$ concentration compared to control. No significant differences were recorded among shoot $\mathrm{Cd}$ concentrations induced by control, cinnamomum biochar and mulberry biochars. In addition, a similar pattern of shoot $\mathrm{Cd}$ concentration was induced by garden waste and mulberry biochars.

\subsection{Change in soil toxic metal concentration induced by biochar among the soil types}

There were no significant $(\mathrm{P}>0.05)$ differences in soil $\mathrm{Cd}$ phytoavailable concentration of all soils incorporated with mulberry biochar (Table 5). However, garden waste biochar treatment showed the highest and significant reduction $(26.4 \pm 1.23 \%$ with $\mathrm{P}<0.01)$ in soil phytoavailable $\mathrm{Cd}$ concentration in Udult followed by what it reduced in Ustalf $(15.7 \pm 1.48 \%)$ and Udept $(9.15 \pm 1.38 \%)$ soils, respectively.

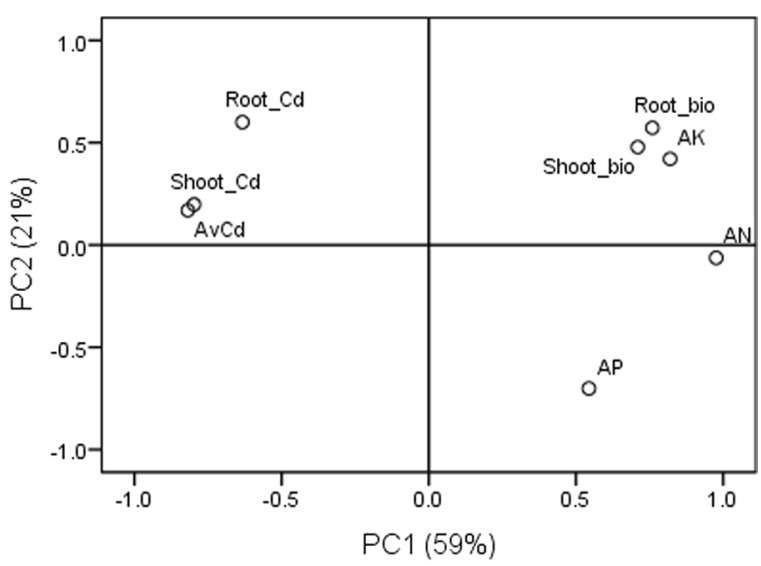

Fig. 3 Principal components analysis among: AvCd: concentration of soil Cd phytoavailable $\left(\mathrm{mg} \mathrm{kg}^{-1}\right)$, Root_Cd: Cd concentration in roots ( $\left.\mathrm{mg} \mathrm{kg}^{-1} \mathrm{DM}\right)$, Root_biomass: root dry biomass ( $\left.\mathrm{g}^{\text {-plant }}\right)$, Shoot_biomass: shoot dry biomass ( $\left.\mathrm{g}^{\text {-plant }}\right)$, AP: available phosphorus concentration in biochar $\left(\mathrm{g} \mathrm{kg}^{-1}\right), \mathrm{Ak}$ : available potassium concentration in biochar $\left(\mathrm{g} \mathrm{kg}^{-1}\right)$ under Udept soil

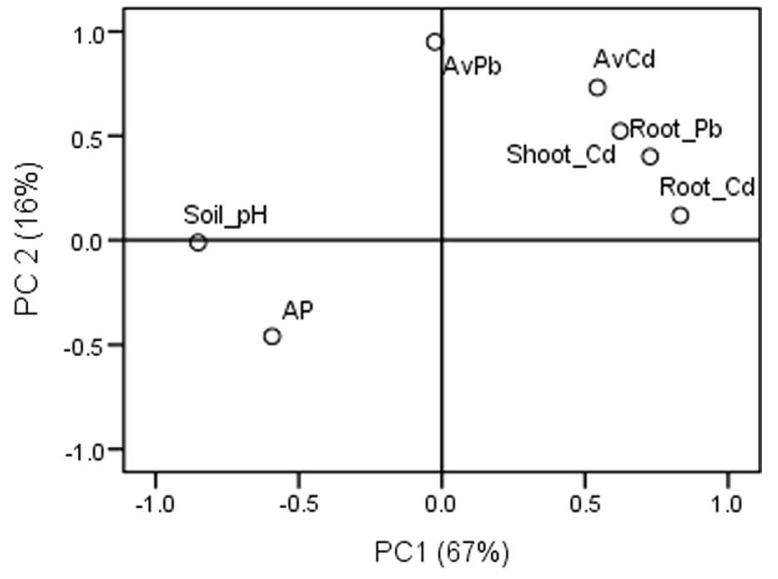

Fig. 4 Principal components analysis among: AvCd: concentration of soil $\mathrm{Cd}$ phytoavailable $\left(\mathrm{mg} \mathrm{kg}^{-1}\right), \mathrm{AvPb}$ : concentration of soil $\mathrm{Pb}$ phytoavailable $\left(\mathrm{mg} \mathrm{kg}^{-1}\right)$, Root_Cd: $\mathrm{Cd}$ concentration in roots ( $\left.\mathrm{mg} \mathrm{kg}^{-1} \mathrm{DM}\right)$, Shoot_Cd: concentration Cd in shoots $\left(\mathrm{mg} \mathrm{kg}^{-1} \mathrm{DM}\right)$, Root_Pb: concentration of $\mathrm{Pb}$ in roots $\left(\mathrm{mg} \mathrm{kg}^{-1} \mathrm{DM}\right), \mathrm{AP}$ : available phosphorus concentration in biochar $\left(\mathrm{g} \mathrm{kg}^{-1}\right)$, Soil _ $\mathrm{pH}$ : soil $\mathrm{pH}$ in Ustalf soil

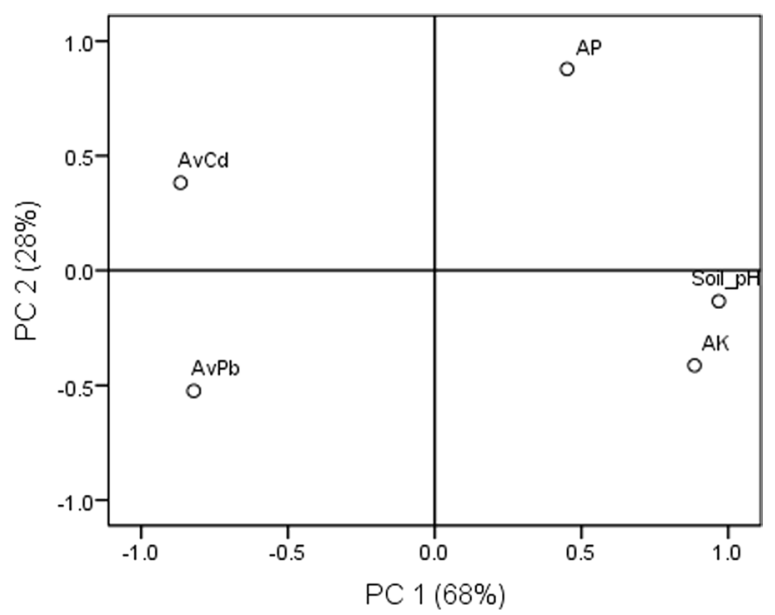

Fig. 5 Principal components analysis among: AvCd: phytoavailable $\mathrm{Cd}$ concentration in soil $\left(\mathrm{mg} \mathrm{kg}^{-1}\right)$, AvPb: phytoavailable $\mathrm{Pb}$ concentration in soil $\left(\mathrm{mg} \mathrm{kg}^{-1}\right)$, soil_pH: soil $\mathrm{pH}, \mathrm{AP}$ : available phosphorus concentration in biochar $\left(\mathrm{g} \mathrm{kg}^{-1}\right)$ in Udult soil 

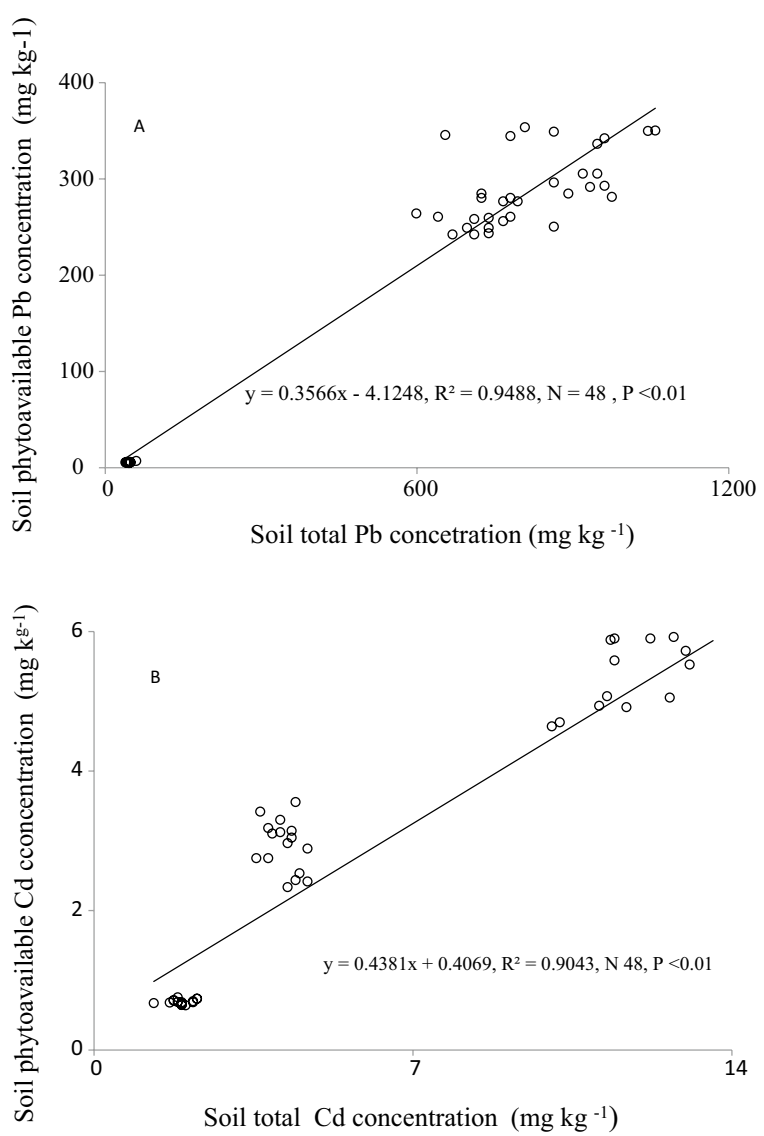

Fig. 6 Correlation between soil total and phytoavailable toxic metal concentrations $\left(\mathrm{mg} \mathrm{kg}^{-1}\right), \mathrm{Pb}(\mathbf{A})$ and $\mathrm{Cd}(\mathbf{B})$

In addition, cinnamomum biochar had its significant and highest reduction in soil Cd mobility in Udult compared to Cd concentration in Udept and Ustalf soils. Compared to untreated soil, garden waste biochar had its highest reduction in soil phytoavailable $\mathrm{Pb}$ concentration in Udult $(16.7 \pm 0.69 \%)$ followed by what it reduced in Ustalf $(6.7 \pm 0.76 \%)$ and Udept $(-7.87 \pm 6.48 \%)$ soils, respectively. Mulberry biochar also lowered $\mathrm{Pb}$ phytoavailability by $15.9 \pm 1.86 \%$ in Udult soil compared with what reduced in Udept and Ustalf soils.

\subsection{Factors controlling soil potential toxic metal concentration and plant uptake}

Three main factors were considered to understand the soil toxic metal immobility and plant uptake (Fig. 3, 4 and 5). In Udept soil, biomass (shoot and root) and phytoavailable $\mathrm{N}$ and $\mathrm{K}$ of all types (cinnamomum, garden waste, mulberry) of biochar were significantly $(\mathrm{P}<0.05)$ and positively correlated $(r=0.66-0.82)$ and related to PC1 (principal component 1; Fig. 3). In addition, root, shoot and soil phytoavailable $\mathrm{Cd}$ concentrations were positively correlated $(\mathrm{r}=0.6-0.71$ with $\mathrm{P}<0.01)$ and related also to PC1. However, they were negatively correlated with dry biomass and biochar available N, P and K concentrations (Fig. 3). For the Ustalf, soil $\mathrm{pH}$ and biochar available $\mathrm{P}$ concentration were positively and significantly $(r=0.67$ with $\mathrm{P}<0.01)$ correlated and related to PC1. However, they were negatively correlated $(r=-0.54$ to $-0.6, \mathrm{P}<0.05)$ with root and shoot $\mathrm{Cd}$, root $\mathrm{Pb}$ and soil phytoavailable $\mathrm{Cd}$ concentration, which related to PC1. Furthermore, the available P concentration in biochar was related to $\mathrm{PC} 2$ and was negatively related (with $\mathrm{r}=-0.42, \mathrm{P}<0.05$ ) to soil phytoavailable $\mathrm{Pb}$ concentration (Fig. 4). In addition, root $\mathrm{Cd}$, shoot $\mathrm{Cd}$, root $\mathrm{Pb}$ and phytoavailable $\mathrm{Cd}$ were positively correlated $(\mathrm{R}=0.54-0.75$, $\mathrm{P}<0.05$ ).

In Udult, the $\mathrm{pH}$ of soil was negatively and significantly correlated $(r=-0.74$ to -0.87 with $\mathrm{P}<0.01)$ with soil phytoavailable $\mathrm{Cd}$ and $\mathrm{Pb}$ and related to $\mathrm{PC} 1$ (Fig. 5). In addition, soil phytoavailable $\mathrm{Pb}$ and biochar available $\mathrm{P}$ concentrations were negatively correlated (Fig. 5); however, biochar available $\mathrm{K}$ and soil $\mathrm{pH}$ were positively correlated and related to PC1. During this study, it was observed that there was significant and positive correlation between soil available and their total toxic metals (Fig. 6).

\section{Discussion}

\subsection{Plant biomass induced by different biochars}

Soil $\mathrm{pH}$ and toxicity of toxic metals are among factors controlling plant physiology and growth (Gentili et al. 2018; Eissa 2019). The death of plants cultivated in Udult with mulberry and cinnamomum biochars and control can be related to both soil extreme acidic $\mathrm{pH}$ and toxicity of $\mathrm{Cd}$ and $\mathrm{Pb}$. The soil $\mathrm{pH}$ negative effect on plant growth is in agreement with Reddy (2017), who reported that soil $\mathrm{pH}$ requirement for Chinese cabbage farming is 5.5-7.0 and lower soil $\mathrm{pH}$ always leads to soil nutrient deficiency. Thus, the young plants cultivated on an extreme acid contaminated soil were not able to have access to soil nutrients (Butchee et al. 2012). Garden waste biochar improved soil $\mathrm{pH}$ from 4.86 (Table 1) to 6.25 (Table 4) due to its high alkalinity associated with its high ash concentration (Table 2), available alkali elements, and surface alkalinity according to Chen et al. (2020) and Nnadiet al. (2019), which was in line with the positive relationship between available K in biochar and soil pH (Fig. 5). This suggested that garden waste biochar applied at rate of $3 \%$ can weaken the negative consequences of extreme acidic soil $\mathrm{pH}$ on plant growth in contaminated soils. Thus, the lower soil $\mathrm{pH}$ recorded in soil amended with mulberry could be related to its lower ash content. 
The plants death in Udult soil could be related to $\mathrm{Cd}$ and $\mathrm{Pb}$ toxicity because biomass had significant negative relationship with soil phytoavailable and biomass toxic metal concentrations (Fig. 3). This suggested that high accumulation of toxic metals in the plant led to plant toxicity, therefore reduction in biomass production (Rizwan et al. 2018). Thus, an increase in biomass toxic metal concentration (Figs. 1 and 2) led to a reduction in biomass (Table 3) production (El Rasafi et al. 2020; Rizwan et al. 2018), therefore, the plant death, which was consistent with Zhai et al. (2020) and Chen et al. (2020), who reported that the $\mathrm{Cd}$ and $\mathrm{Pb}$ toxicity negatively affect the plants cultivated in acidic contaminated soils. This suggested that garden waste biochar applied at rate of $3 \%$ can weaken the negative consequences of toxic metals on the plants cultivated in acidic contaminated soils. However, further studies are warranted on the Udult soil to understand the reasons behind the plant mortality. In addition, relatively more death of plants under cinnamomum and mulberry biochars compared to garden waste biochar in Udult soil and survival of all plants in Udept and Ustalf soils demonstrated that biochar effects on soil chemical properties varied with biochar properties (related to its feedstock) and soil types. The different effects among biochars derived from the same pyrolysis temperature $\left(450{ }^{\circ} \mathrm{C}\right)$ but different feedstocks on soil toxic metal reduction could be attributed to their differences in physicochemical properties (Table 2), which was consistent with Tomczyk et al. (2020) and Chen et al. (2020). They also observed that biochar properties such $\mathrm{pH}$, ash content, porosity, surface alkalinity, active functional groups and alkali elements mainly depend on biochar feedstocks, therefore, biocharsderived from different feedstocks but produced at similar pyrolysis temperatures have different effects on the reduction of toxic metals in soil (Chen et al. 2018).

In addition, the lack of an improvement in Udult soil $\mathrm{pH}$ to the desired soil $\mathrm{pH}$ (5.5-7.0 for example; Table 3) following the application of mulberry and cinnamomum biochars might be related to their lower ash concentration, $\mathrm{pH}$ and available alkali elements (Table 2). Therefore, the biochar feedstock plays an important role in biochar properties, which might be the source of different effects induced by biochar on Udult soil for improvement in its $\mathrm{pH}$ with reduction in soil phytoavailable $\mathrm{Cd}$ and $\mathrm{Pb}$ concentrations (Rinklebe et al. 2016).

We observed that garden waste and mulberry biochars in Udept soil induced a high total biomass compared to cinnamomum and control treatments. The high biomass recorded with garden waste and mulberry biomass in Udept soil could be related to both the reduction in soil phytoavailable $\mathrm{Cd}$ concentration (Table 4 ) and their high concentration of plant nutrients (N, P, K; Table 2). For example, the concentration of biochar available nutrients $(\mathrm{N}, \mathrm{P}, \mathrm{K})$ had a positive relationship with biomass (Fig. 3). It was in agreement with Chen et al. (2020), who found that pig and manure biochars generally provided greater impact on plant production compared to wood biochars due to their high $\mathrm{N}, \mathrm{P}$ and $\mathrm{K}$ concentrations. They also reported that the addition of biochars could be a key factor immobilizing soil toxic metals and decreasing their plant uptake; thus promoting biomass production after soil amendment with biochar.

\subsection{Soil chemical properties derived from different biochar amendments}

Phytoavailability of potentially toxic metal concentration generally has a positive relationship with their total concentration of soil (Abuzaid and Bassouny 2020). We also observed that soil phytoavailable toxic metals and their total concentrations were positively and significantly correlated (Fig. 6). Therefore, the reduction in soil total toxic metal concentration could induce the reduction in soil phytoavailable toxic metal concentration. This suggested that the available soil toxic metals were originated from total soil toxic metals.

Furthermore, the amendment of the garden waste and mulberry biochars to the Udept, Ustalf and Udult soils significantly reduced soil phytoavailable $\mathrm{Cd}$ concentration compared to untreated soil and no significant $(\mathrm{P}>0.05)$ difference was recorded between untreated soil and treatment of cinnamomum biochar in all types of soil (Table 4). For all types of soil, the reduction in soil phytoavailable $\mathrm{Cd}$ concentration can be related to the high available $\mathrm{P}$ concentration in garden waste and mulberry biochars (Table 2), which had a negative relationship with soil phytoavailable Cd (Figs. 3, 4 and 5). This indicated that the biochar available $P$ concentration was of importance in metal immobilization through the complex of metal phosphates and phosphide precipitates. This finding was consistent with Penido et al. (2019) and Qin et al. (2018), who found that biochar surface had effective functional groups, which presented strong sorption capacities for $\mathrm{Cd}$. Thus, the available phosphorus in biochar reacts with $\mathrm{Cd}$ to make $\mathrm{Cd}$-phosphate or phosphide.

In addition, the reduction in soil $\mathrm{Cd}$ concentration observed in Ustalf and Udult soils amended with garden waste and mulberry biochars compared with untreated soil can be related also to soil $\mathrm{pH}$ improvement induced by garden waste and mulberry biochars, which was in line with the negative relationship observed between soil phytoavailable $\mathrm{Cd}$ concentration and soil $\mathrm{pH}$ in Ustalf and Udult soils (Figs. 4 and 5). This finding was in agreement with Jing et al. (2019), Penido et al. (2019), Chen et al. (2020) and Beiyuan et al. (2020), who suggested that a reduction in soil phytoavailable toxic metals was more related to biochar soil $\mathrm{pH}$ improvement (Table 4). The lower soil phytoavailable $\mathrm{Pb}$ concentration induced by garden waste and mulberry biochars compared to what recorded with cinnamomum and 
control in Ustalf and Udelt soils can mainly be attributed to their high phytoavailable $\mathrm{P}$ concentration (Table 2) and their soil pH improvement (El-Naggar et al. 2018). Thus, the available $\mathrm{P}$ in biochar reacted with $\mathrm{Pb}$ to make $\mathrm{Pb}$-phosphate or $\mathrm{Pb}$-phosphide, which was in agreement with Kwak et al. (2019). Indeed, the available P in biochar and concentrations of soil phytoavailable $\mathrm{Pb}$ had significant negative relationship (Figs. 4 and 5), thus available $\mathrm{P}$ in biochar complexed with metals (Albert et al. 2021) to metal phosphate or phosphide.

With the Udult soil, the high soil $\mathrm{pH}$ induced by garden waste and mulberry compared to cinnamomum and control can be related to their high ash concentration (Table 2) that induced a liming effect (Jing et al. 2019; Chen et al. 2020). The increase in soil $\mathrm{pH}$ induced by garden waste and mulberry biochars can be correlated with their high $\mathrm{pH}(9.48$ for garden waste biochar and 9.28 for mulberry biochar, Table 2). This suggested that alkaline biochars amendment to the soil released the alkali salts into soil, thus, increasing soil $\mathrm{pH}$, which was in agreement with Chen et al. (2020). Furthermore, during the pyrolysis process, the nutrients in garden waste and mulberry $(\mathrm{Ca}, \mathrm{K}, \mathrm{Mg})$ can be changed into carbonates or oxides, which combined with $\mathrm{H}^{+}$in acidic soil, thus increasing soil pH (Dai et al. 2017). In addition, garden waste and mulberry biochars produced at $450{ }^{\circ} \mathrm{C}$ may have abundant functional groups (-COO- and $\mathrm{O}-$ ), which can also complex with $\mathrm{H}^{+}$, thus, increasing soil $\mathrm{pH}$ (Yuan and $\mathrm{Xu}$ 2011). Thus, functional groups of biochar immobilized $\mathrm{Cd}$ and $\mathrm{Pb}$ by transforming the readily available fractions to more stable metal-organic complex resulting in decreasing the mobility of $\mathrm{Cd}$ and $\mathrm{Pb}$.

Compared to control, the soil total $\mathrm{N}$ and $\mathrm{P}$ obviously increased after biochar amendment to the soil (Zhang et al. 2019) because the application of a high dose of biochar with the high levels of total $\mathrm{P}$ and $\mathrm{N}$ provides a large amount of $\mathrm{N}$ and $\mathrm{P}$ to the soil (De Figueiredo et al. 2020). During this case study, we found that there were no significant differences $(\mathrm{P}>0.05)$ among all three types of biochar in Udept soil for soil total $\mathrm{N}$ and $\mathrm{P}$ concentrations. However, it was recorded that the garden waste and mulberry biochar application to the Ustalf soil significantly increased soil total $\mathrm{N}$ and $\mathrm{P}$ compared to untreated soil and treatment cinnamomum biochar. An increase in soil total $\mathrm{N}$ and $\mathrm{P}$ induced by garden waste and mulberry application at $3 \%$ can be related to their richness in $\mathrm{N}$ and $\mathrm{P}$ (Zhang et al. 2019).

\subsection{Influence of different types of biochar on Cd and $\mathrm{Pb}$ phytouptake}

This study identified that garden waste and mulberry biochars generally reduced root $\mathrm{Pb}$ (in Ustalf soil) and $\mathrm{Cd}$ (in Udept and Ustalf soils) concentrations compared to cinnamomum biochar and control (Figs. 1 and 2). The reduction in root $\mathrm{Pb}$ and $\mathrm{Cd}$ concentrations of the plants grown in Udept and Ustalf soil amended with garden waste and mulberry biochars can be attributed to soil $\mathrm{pH}$ improvement and immobilization in soil phytoavailable concentration of $\mathrm{Cd}$ and $\mathrm{Pb}$ induced by available phosphorus and ash concentration in those biochars (Table 4, Figs. 3 and 5). Similarly, $\mathrm{Xu}$ et al. (2020) and Beiyuan et al. (2017) identified that biochar derived from kitchen waste, corn straw, peanut hulls, coconut-fiber and oak trunk decreased soil phytoavailable $\mathrm{Cd}$ and $\mathrm{Pb}$ concentrations. The authors reported that it was attributed to soil $\mathrm{pH}$ improvement by application of biochars (containing various functional groups, i.e. $-\mathrm{COOH},-\mathrm{NH}_{2}$, $-\mathrm{C}=\mathrm{O}$ and ionic species, like $\mathrm{PO}_{4}, \mathrm{CO}_{3}$ ), which can complex with soil toxic metal cations (Fang et al. 2020), thus, the root $\mathrm{Cd}$ and $\mathrm{Pb}$ concentrations were reduced, which had significantly negative relationship with soil pH (Fig. 4).

The contaminated soil amended with biochar reduced the root-shoot translocation of toxic metals (Eissa 2019; Chen et al. 2020). Furthermore, Albert et al. (2021) found that the concentrations of toxic metals in roots and shoots were linearly and positively related, thus, $\mathrm{Cd}$ concentration reduction in root could result in decrease of shoot $\mathrm{Cd}$ concentration. During this study, we observed that garden waste and mulberry biochars induced lower shoot $\mathrm{Cd}$ concentration in Udept and Ustalf soils compared to that observed with cinnamomum biochar and control. Thus, reduction in shoot $\mathrm{Cd}$ concentration induced by garden waste and mulberry compared to untreated soil and cinnamomum biochar can be attributed to lower rood $\mathrm{Cd}$ concentration induced by garden waste and mulberry biochars compared to control and cinnamomum biochar in Udult and Ustalf soils (Fig. 4), which was in line with positive correlation between concentrations of $\mathrm{Cd}$ in roots and shoots (Figs. 3 and 4).

\section{Conclusions}

This study showed the impacts of biochar and soil chemical properties on soil phytoavailable $\mathrm{Pb}$ and $\mathrm{Cd}$ and their plant uptake following biochar amendments. The alkaline garden waste biochar improved Udult soil $\mathrm{pH}$, allowing Chinese cabbage to survive in extreme acidic soil contaminated with toxic metals. The garden waste biochar and the mulberry biochar reduced soil phytoavailable concentrations of toxic metals $(\mathrm{Cd}$ and $\mathrm{Pb})$ in both alkaline and acidic soils. Compared to untreated soil, they reduced also plant toxic metal uptake. However, they increased soil nutrients such as $\mathrm{N}$ and $\mathrm{P}$. There was no important effect of biochar originated from cinnamomum on phytoavailable $\mathrm{Cd}$ and $\mathrm{Pb}$ in alkaline and acidic soils, but garden waste biochar lowered $\mathrm{Cd}$ and $\mathrm{Pb}$ availability in the acidic and alkaline soils.

Garden waste and mulberry biochars had high nutrient content, $\mathrm{pH}$ and ash content than biochar derived from 
cinnamomum feedstock. Therefore, garden waste biochar and mulberry biochar had high potential to improve soil chemical properties, thereby enhancing the crop biomass. Factors controlling metal phytoavailable and plant uptake were mainly soil $\mathrm{pH}$ and the available $\mathrm{P}$ concentration in biochar, which might complex with metal to form metal phosphate or phosphide. Thus, biochar derived from garden waste and mulberry wood and produced at pyrolysis temperature of $450{ }^{\circ} \mathrm{C}$ can be amended into the soil to reduce the mobility of soil toxic metal and plant uptake. However, this work suggests that it is important to know the soil and biochar conditions (properties) before using them to mitigate toxic metal contaminated soil with biochar (pyrolysis temperature of $450{ }^{\circ} \mathrm{C}$ ) at rate of $3 \%$.

Author contributions AAH: Conceptualization, data curation, investigation, software, writing - original draft. PJ: conceptualization, formal analysis, writing-review and editing. NKN: data curation, writing — review and editing. LVZ: formal analysis, writing - review and editing. XL: software, methodology, writing-original draft. LH: Data curation, investigation. LW: conceptualization, methodology. $\mathrm{XZ}$ : data curation, writing-review and editing. QH: methodology, formal analysis. YH: formal analysis, writing-review and editing. XW: data curation, investigation. HW: conceptualization, writing-review and editing. ZL, ZH: conceptualization, writing-review and editing, supervision.

Funding and acknowledgements The financial supports from Special fund for Agricultural competitive industry discipline team building project of Guangdong Academy of Agricultural Sciences (202120TD); Guangdong Academy of Agricultural Sciences Dean Fund, China (BZ201903, BZ202001); Natural Science Foundation of China (41571313, 21876027); Department of Science and Technology of Guangdong Province, China (2019B121201003); The National Project for Agricultural Technology System (CARS-18); Guangdong Provincial Special Fund For Modern Agriculture Industry Technology Innovation Teams (2019KJ109, 2019KJ148) are gratefully acknowledged.

Availability of data and materials The data analyzed during this study which support its findings are available on request from the corresponding author.

\section{Declarations}

Conflicts of interest The authors have no conflicts of interest to disclose, financial or otherwise.

Open Access This article is licensed under a Creative Commons Attribution 4.0 International License, which permits use, sharing, adaptation, distribution and reproduction in any medium or format, as long as you give appropriate credit to the original author(s) and the source, provide a link to the Creative Commons licence, and indicate if changes were made. The images or other third party material in this article are included in the article's Creative Commons licence, unless indicated otherwise in a credit line to the material. If material is not included in the article's Creative Commons licence and your intended use is not permitted by statutory regulation or exceeds the permitted use, you will need to obtain permission directly from the copyright holder. To view a copy of this licence, visit http://creativecommons.org/licenses/by/4.0/.

\section{References}

Abdin Y, Usman A, Ok YS, Tsang YF, Al-Wabel M (2019) Competitive sorption and availability of coexisting heavy metals in mining-contaminated soil: contrasting effects of mesquite and fishbone biochars. Environ Res 81:08846

Abuzaid AS, Bassouny MA (2020) Total and DTPA-extractable forms of potentially toxic metals in soils of rice fields, north Nile Delta of Egypt. Environ Technol Innov 18:100717

Albert HA, Li X, Jeyakumar P, Wei L, Huang L, Huang Q, Kamran M, Shaheen SM, Hou D, Rinklebe J, Liu Z, Wang H (2021) Influence of biochar and soil properties on soil and plant tissue concentrations of $\mathrm{Cd}$ and $\mathrm{Pb}$ : a meta-analysis. Sci Total Environ 755:142582

Anwar H, Shahid M, Natasha Niazi NK, Khalid S, Tariq TZ, Ahmad S, Nadeem M, Abbas G (2020) Risk assessment of potentially toxic metal(loid)s in Vigna radiata L. under wastewater and freshwater irrigation. Chemosphere 265:129124

Askeland M, Clarke BO, Cheema SA, Mendez A, Gasco G, PazFerreiro J (2020) Biochar sorption of PFOS, PFOA, PFHxS and PFHxA in two soils with contrasting texture. Chemosphere 249:126072

Babalola OB, Ojuederie OB (2017) Microbial and plant-assisted bioremediation of heavy metal polluted environments: a review. Int $\mathrm{J}$ Environ Res Public Health 4:1504

Beiyuan J, Awad YM, Beckers F, Tsang DCW, Ok YS, Rinklebe J (2017) Mobility and phytoavailability of $\mathrm{As}$ and $\mathrm{Pb}$ in a contaminated soil using pine sawdust biochar under systematic change of redox conditions. Chemosphere 178:110-118

Beiyuan J, Awad YM, Beckers F, Wang J, Tsang DCW, Ok YS, Wang SL, Wang H, Rinklebe J (2020) (Im)mobilization and speciation of lead under dynamic redox conditions in a contaminated soil amended with pine sawdust biochar. Environ Int 135:105376

Butchee K, Arnall DB, Sutradhar A, Godsey C, Zhang H, Penn C (2012) Determining critical soil $\mathrm{pH}$ for grain sorghum production. Int J Agron 2012:130254

Camps-Arbestain M, Amonette JE, Singh B, Wang T, Schmidt HP (2015) A biochar classification system and associated test methods. In: Lehmann J, Joseph S (eds) Routledge, New York

Chen D, Liu X, Bian R, Cheng K, Zhang X, Zheng J, Joseph S, Crowley D, Pan G, Li L (2018) Effects of biochar on availability and plant uptake of heavy metals: a meta-analysis. J Environ Manage 222:76-85

Chen H, Yang X, Wang H, Sarkar B, Shaheen SM, Gielen G, Bolan N, Guo J, Che L, Sun H, Rinklebe J (2020) Animal carcassand wood-derived biochars improved nutrient bioavailability, enzyme activity, and plant growth in metal-phthalic acid ester co-contaminated soils: a trial for reclamation and improvement of degraded soils. J Environ Manage 261:110246

Chen H, Qin P, Yang X, Bhatnagar A, Shaheen SM, Rinklebe J, Wu F, Xu S, Che L, Wang H (2021) Sorption of diethyl phthalate and cadmium by pig carcass and green waste-derived biochars under single and binary systems. Environ Res 193:110594

Dai Z, Zhang X, Tang C, Muhammad N, Wu J, Brookes PC, Xu J (2017) Potential role of biochars in decreasing soil acidification-a critical review. Sci Total Environ 581-582:601-611

De Figueiredo CC, Pinheiro TD, de Oliveira LEZ, De Araujo ASS, Cosser TR, Paz-Ferreiro J (2020) Direct and residual effect of biochar derived from biosolids on soil phosphorus pools: a fouryear field assessment. Sci Total Environ 739:140013

Eduah JO, Nartey EK, Abekoe MK, Henriksen SW, Neumann Andersen MN (2020) Mechanism of orthophosphate (PO-P) adsorption onto different biochars. Environ Technol Innov $17: 100572$ 
Eissa MA (2019) Effect of cow manure biochar on heavy metals uptake and translocation. Arab J Geosci 12:48-50

El Rasafi T, Oukarroum A, Haddioui A, Song H, Kwon EE, Bolan N, Tack FMG, Sebastian A, Prasad MNV, Rinklebe J (2020) Cadmium stress in plants: a critical review of the effects, mechanisms, and tolerance strategies. Crit Rev Environ Sci Technol. https://doi. org/10.1080/10643389.2020.1835435

El-Naggar A, Shaheen SM, Ok YS, Rinklebe J (2018) Biochar affects the dissolved and colloidal concentrations of $\mathrm{Cd}, \mathrm{Cu}, \mathrm{Ni}$, and $\mathrm{Zn}$ and their phytoavailability and potential mobility in a mining soil under dynamic redox-conditions. Sci Total Environ 624:1059-1071

Fang Z, Gao Y, Bolan N, Shaheen SM, Xu S, Wu X, Xu X, Hu H, Lin J, Zhang F, Li J, Rinklebe J, Wang H (2020) Conversion of biological solid waste to graphene-containing biochar for water remediation: a critical review. Chem Eng J 390:124611

Food and Agriculture Organization and World Health Organization (2015) General standard for contaminants and toxins in food and feed, CODEX STAN 193-1995. World Health Organization, Geneva

Gan Y, Wang L, Yang G, Dai J, Wang R, Wang W (2017) Multiple factors impact the contents of heavy metals in vegetables in high natural background area of China. Chemosphere 184:1388-1395

GB15618-2018 (2018) Soil environmental quality risk control standard for soil contamination of agricultural land. http://www.lddoc.cn/p1948648.html (in Chinese)

Gentili R, Ambrosini R, Montagnani C, Caronni S, Citterio S (2018) Effect of soil $\mathrm{pH}$ on the growth, reproductive investment and pollen allergenicity of Ambrosia artemisiifolia L. Front Plant Sci 9:1335

Guan DX, Sun FS, Yu GH, Polizzotto ML, Liu YG (2018) Total and available metal concentrations in soils from six long-term fertilization sites across China. Environ Sci Pollut Res. https://doi.org/ 10.1007/s11356-018-3143-3

Gupta N, Yadav KK, Kumar V, Kumar S, Chadd RP, Kumard A (2019) Trace elements in soil-vegetables interface: translocation, bioaccumulation, toxicity and amelioration-a review Sci. Total Environ 651:2927-2942

Hamid Y, Tang L, Hussain B, Usman M, Gurajala HK, Rashid MS, He Z, Yang X (2020) Efficiency of lime, biochar, Fe containing biochar and composite amendments for $\mathrm{Cd}$ and $\mathrm{Pb}$ immobilization in a co-contaminated alluvial soil. Environ Pollut 257:113609

Huang Y, Sheng H, Zhou P, Zhang Y (2020) Remediation of Cd-contaminated acidic paddy fields with four-year consecutive liming. Ecotoxicol Environ Saf 188:109903

Hussain MM, Wang J, Bibi I, Shahid M, Niazi NK, Iqbal J, Mian IA, Shaheen SM, Bashir S, Shah NS, Hina K, Rinklebe J (2021) Arsenic speciation and biotransformation pathways in the aquatic ecosystem: the significance of algae. J Hazard Mater 403:124027

Jing F, Chen C, Chen X, Liu W, Wen X, Hu S, Yang Z, Guo B, Xu Y, Yu Q (2019) Effects of wheat straw derived biochar on cadmium availability in a paddy soil and its accumulation in rice. Environ Pollut 257:113592

Jorg Rinklebe J, Shaheen SM, Schroter F, Rennert T (2016) Exploiting biogeochemical and spectroscopic techniques to assess the geochemical distribution and release dynamics of chromium and lead in a contaminated floodplain soil. Chemosphere 150:390-397

Kwak JH, Islam MS, Wang S, Messele SA, Naeth MA, El-Din MG, Chang SX (2019) Biochar properties and lead(II) adsorption capacity depend on feedstock type, pyrolysis temperature, and steam activation. Chemosphere 231:393-404

Li H, Ye X, Geng Z, Zhou H, Guo X, Zhang Y, Zhao H, Wang G (2016) The influence of biochar type on long-term stabilization for $\mathrm{Cd}$ and $\mathrm{Cu}$ in contaminated paddy soils. J Hazard Mater 304:40-48
Li H, Xu H, Zhou S, Yu Y, Li H, Zhou C, Chen Y, Li Y, Wang M, Wang G (2018) Distribution and transformation of lead in rice plants grown in contaminated soil amended with biochar and lime. Ecotoxicol Environ Saf 165:589-596

Li J, Wang SL, Zhang J, Zheng L, Chen D, Wu Z, Shaheen SM, Rinklebe J, Ok YS, Wang H, Wu W (2020) Coconut-fiber biochar reduced the bioavailability of lead but increased its translocation rate in rice plants: elucidation of immobilization mechanisms and significance of iron plaque barrier on roots using spectroscopic techniques. J Hazard Mater 389:122117

Lu RK (2000) Methods of soil and agro-chemical analysis. China Agricultural Science and Technology Press, Beijing (in Chinese)

Lu K, Yang X, Gielen G, Bolan N, Ok YS, Niazi NK, Xu S, Yuan G, Chen X, Zhang X, Liu D, Song Z, Liu X, Wang H (2017) Effect of bamboo and rice straw biochars on the mobility and redistribution of heavy metals $(\mathrm{Cd}, \mathrm{Cu}, \mathrm{Pb}$ and $\mathrm{Zn})$ in contaminated soil. $\mathrm{J}$ Environ Manag 186:285-292

Lu L, Yu W, Wang Y, Zhang K, Zhu X, Zhang Y, Wu Y, Ullah H, Xiao X, Chen B (2020) Application of biochar-based materials in environmental remediation: from multi-level structures to specific devices. Biochar 2(1):1-31

Luo X, Bing H, Luo Z, Wang Y, Jin L (2019) Impacts of atmospheric particulate matter pollution on environmental biogeochemistry of trace metals in soil-plant system: a review. Environ Pollut 255:113138

Mecka ML, Mudimbua D, Daviesb TC (2020) Accumulation of potentially harmful elements in edible parts of vegetables grown on two different geological substrates in Zimbabwe. J Geochem Explor 208:106392

Mohamed I, Guo-shi Zhang GS, Li ZG, Liu Y, Chen F, Dai K (2015) Ecological restoration of an acidic Cd contaminated soil using bamboo biochar application. Ecol Eng 84:67-76

Natasha, Bibi I, Shahid M, Niazi NK, Younas F, Naqvi SR, Shaheen SM, Imran M, Wang H, Hussaini KM, Zhang H, Rinklebe J (2021) Hydrogeochemical and health risk evaluation of arsenic in shallow and deep aquifers along the different floodplains of Punjab, Pakistan. J Hazard Mater 402:124074

Nnadi EO, Mbah CN, Nweke AI, Njoku C (2019) Physicochemical properties of an acid ultisol subjected to different tillage practices and wood-ash amendment: impact on heavy metal concentrations in soil and Castor plant. Soil Tillage Res 194:104288

Palansooriya KN, Shaheen SM, Chen SS, Tsang DCW, Hashimoto Y, Hou D, Ok YS (2020) Soil amendments for immobilization of potentially toxic elements in contaminated soils: a critical review. Environ Int 134:05046

Pan H, Yang X, Chen H, Sarkar B, Bolan N, Shaheen SM, Wu F, Che L, Ma Y, Rinklebe J, Wang H (2021) Pristine and iron-engineered animal- and plant-derived biochars enhanced bacterial abundance and immobilized arsenic and lead in a contaminated soil. Sci Total Environ 763:144218

Penido ES, Melo LCA, Guilherme LRG, Bianchi ML (2019) Cadmium binding mechanisms and adsorption capacity by novel phosphorus/magnesium-engineered biochars. Sci Total Environ 671:1134-1143

Qiao Y, Crowley D, Wang K, Zhang H, Li H (2015) Effects of biochar and arbuscular mycorrhizae on bioavailability of potentially toxic elements in an aged contaminated soil. Environ Pollut 206:636-643

Qin P, Wang H, Yang X, He L, Müller K, Shaheen SM, Xu S, Rinklebe J, Tsang DCW, Ok YS, Bolan N, Song Z, Che L, Xu X (2018) Bamboo- and pig-derived biochars reduce leaching losses of dibutyl phthalate, cadmium, and lead from co-contaminated soils. Chemosphere 198:450-459

Qin SY, Liu HE, Nie ZJ, Rengel Z, Gao W, Li C, Zhao P (2020) Toxicity of cadmium and its competition with mineral nutrients for uptake by plants: a review. Pedosphere 30:168-180 
Reddy J (2017) Chinese cabbage farming information. Agri Farming. https://www.agrifarming.in/chinese-cabbage-farming. Accessed 4 Dec 2020

Rizwan M, Ali S, Rehman MZU, Rinklebe J, Tsang DCW, Bashir A, Maqbool A, Tack FMG, Ok YS (2018) Cadmium phytoremediation potential of Brassica crop species: a review. Sci Total Environ 631-632:1175-1191

Suliman W, Harsh JB, Abu-Lail NI, Fortuna AM, Dallmeyer I, Garcia-Perez M (2016) Influence of feedstock source and pyrolysis temperature on biochar bulk and surface properties. Biomass Bioenerg 84:37-48

Tomczyk A, Sokoowska Z, Boguta P (2020) Biochar physicochemical properties: pyrolysis temperature and feedstock kind effects. Rev Environ Sci Biotechnol 19:191-215

Ubeynarayana N, Jeyakumar P, Bishop P, Pereira RC, Anderson CWN (2021) Effect of soil cadmium on root organic acid secretion by forage crops. Environ Pollut 268:115839

Uchimiya M, Chang S, Klasson KT (2011) Screening biochars for heavy metal retention in soil: role of oxygen functional groups. $\mathrm{J}$ Hazard Mater 190:432-441

Wang L, Ok YS, Tsang DCW, Alessi DS, Rinklebe J, Wang H, Mašek O, Hou R, O'Connor D, Hou D (2020) New trends in biochar pyrolysis and modification strategies: feedstock, pyrolysis conditions, sustainability concerns and implications for soil amendment. Soil Use Manag 36:358-386

Wei L, Huang Y, Huang L, Li Y, Huang Q, Xu G, Müller K, Wang $\mathrm{H}$, Ok YS, Liu Z (2020) The ratio of H/C is a useful parameter to predict adsorption of the herbicide metolachlor to biochars. Environ Res 184:109324

Wen E, Yang X, Chen H, Shaheen SM, Sarkar B, Xu S, Song H, Liang Y, Rinklebe J, Hou D, Li Y, Wu F, Pohořelý M, Wong JWC, Wang H (2021) Iron-modified biochar and water management regime-induced changes in plant growth, enzyme activities, and phytoavailability of arsenic, cadmium and lead in a paddy soil. $\mathrm{J}$ Hazard Mater 22:124344
Wilk M, Magdziarz A, Jayaraman K, Szymańska-Chargot M, Gökalp I (2019) Hydrothermal carbonization characteristics of sewage sludge and lignocellulosic biomass. A Comparative Study. Biomass Bioenergy 120:166-175

Wu P, Wang Z, Wang H, Bolan NS, Wang Y, Chen W (2020a) Visualizing the emerging trends of biochar research and applications in 2019: a scientometric analysis and review. Biochar 2(2):135-150

Wu S, Zhang Y, Tan Q, Sun X, Wei W, Hu C (2020b) Biochar is superior to lime in improving acidic soil properties and fruit quality of Satsuma mandarin. Sci Total Environ 714:136722

Xiao R, Wang P, Mi S, Ali A, Liu X, Li Y, Zhang Z (2019) Effects of crop straw and its derived biochar on the mobility and bioavailability in $\mathrm{Cd}$ and $\mathrm{Zn}$ in two smelter-contaminated alkaline soils. Ecotoxicol Environ Saf 181:155-163

Xu C, Zhao J, Yang W, He L, Wei W, Tan X, Lin A (2020) Evaluation of biochar pyrolyzed from kitchen waste, corn straw, and peanut hulls on immobilization of $\mathrm{Pb}$ and $\mathrm{Cd}$ in contaminated soil. Environ Pollut 261:114133

Yuan JH, Xu RK (2011) The amelioration effects of low temperature biochar generated from nine crop residues on an acidic Ultisol. Soil Use Manag 27:110-115

Zhai Y, Wang Z, Wang G, Peijnenburg WJGM, Vijver MG (2020) The fate and toxicity of $\mathrm{Pb}$-based perovskite nanoparticles on soil bacterial community: impacts of $\mathrm{pH}$, humic acid, and divalent cations. Chemosphere 249:126564

Zhang Q, Song Y, Wu Z, Yan X, Xiong Z (2019) Effects of six-year biochar amendment on soil aggregation, crop growth, and nitrogen and phosphorus use efficiencies in a rice-wheat rotation. J Clean Prod 242:118435

Zhou YL, Li CM, Sun B (2017) Nitrogen use efficiency of rice under Cd contamination: impact of rice cultivar versus soil type. Pedosphere 27:1092-1104 